\title{
Prognostic and Predictive Molecular Markers in Cholangiocarcinoma
}

\author{
Sandra Pavicevic ${ }^{1}(\mathbb{D})$, Sophie Reichelt ${ }^{1}\left(\mathbb{D}\right.$, Deniz Uluk $^{1}\left(\mathbb{D}\right.$, Isabella Lurje ${ }^{2}\left(\mathbb{D}\right.$, Cornelius Engelmann ${ }^{2}$, \\ Dominik P. Modest ${ }^{3}$, Uwe Pelzer ${ }^{3}{ }^{\mathbb{D}}$, Felix Krenzien ${ }^{1} \mathbb{D}$, Nathanael Raschzok ${ }^{1} \mathbb{D}$, Christian Benzing ${ }^{1}$, \\ Igor M. Sauer ${ }^{1}{ }^{(D}$, Sebastian Stintzing ${ }^{3}$, Frank Tacke ${ }^{2}{ }^{\mathbb{D}}$, Wenzel Schöning ${ }^{1}$, Moritz Schmelzle ${ }^{1}$, \\ Johann Pratschke ${ }^{1}$ and Georg Lurje ${ }^{1, *(D)}$
}

check for updates

Citation: Pavicevic, S.; Reichelt, S.; Uluk, D.; Lurje, I.; Engelmann, C.; Modest, D.P.; Pelzer, U.; Krenzien, F.; Raschzok, N.; Benzing, C.; et al. Prognostic and Predictive Molecular Markers in Cholangiocarcinoma. Cancers 2022, 14, 1026. https:// doi.org/10.3390/cancers14041026 Academic Editor: Carlos S. Moreno

Received: 18 January 2022 Accepted: 9 February 2022 Published: 17 February 2022

Publisher's Note: MDPI stays neutral with regard to jurisdictional claims in published maps and institutional affiliations.

Copyright: (C) 2022 by the authors. Licensee MDPI, Basel, Switzerland. This article is an open access article distributed under the terms and conditions of the Creative Commons Attribution (CC BY) license (https:// creativecommons.org/licenses/by/ $4.0 /)$.
1 Department of Surgery, Campus Charité Mitte, Campus Virchow Klinikum, Charité-Universitätsmedizin Berlin, 13353 Berlin, Germany; sandra.pavicevic@charite.de (S.P.); sophie.reichelt1@charite.de (S.R.); deniz.uluk@charite.de (D.U.); felix.krenzien@charite.de (F.K.); nathanael.raschzok@charite.de (N.R.); christian.benzing@charite.de (C.B.); igor.sauer@charite.de (I.M.S.); wenzel.schoening@charite.de (W.S.); moritz.schmelzle@charite.de (M.S.); johann.pratschke@charite.de (J.P.)

2 Department of Gastroenterology and Hepatology, Campus Charité Mitte, Campus Virchow Klinikum, Charité-Universitätsmedizin Berlin, 13353 Berlin, Germany; isabella.lurje@charite.de (I.L.); cornelius.engelmann@charite.de (C.E.); frank.tacke@charite.de (F.T.)

3 Department of Hematology, Oncology and Cancer Immunology, Campus Charité Mitte, Campus Virchow Klinikum, Charité-Universitätsmedizin Berlin, 13353 Berlin, Germany; dominik.modest@charite.de (D.P.M.); uwe.pelzer@charite.de (U.P.); sebastian.stinzing@charite.de (S.S.)

* Correspondence: georg.lurje@charite.de; Tel.: +49-30-450-652-339; Fax: +49-30-450-552-900

Simple Summary: Cholangiocarcinoma (CCA) is a heterogenous and aggressive malignancy of the intra- and extrahepatic biliary tract, marked by a steeply rising incidence on a global scale. While surgery remains the only curative treatment option, most patients present with advanced or unresectable disease, and are, therefore, treated with systemic therapy, albeit with limited benefit. Biomarkers obtained from either the patients' serum or tumor tissue might facilitate therapy guidance by selecting patients who would benefit the most from surgical and adjuvant treatment strategies, as well as by identifying those with higher risk of disease recurrence. Furthermore, several genetic aberrations in CCA have been linked with improved response upon targeted therapies, thus highlighting their role as predictive biomarkers. In this review we provide an overview of currently known prognostic and predictive biomarkers and discuss their role in CCA.

Abstract: Cholangiocarcinoma (CCA) is the second most common primary liver cancer and subsumes a heterogeneous group of malignant tumors arising from the intra- or extrahepatic biliary tract epithelium. A rising mortality from CCA has been reported worldwide during the last decade, despite significant improvement of surgical and palliative treatment. Over $50 \%$ of CCAs originate from proximal extrahepatic bile ducts and constitute the most common CCA entity in the Western world. Clinicopathological characteristics such as lymph node status and poor differentiation remain the best-studied, but imperfect prognostic factors. The identification of prognostic molecular markers as an adjunct to traditional staging systems may not only facilitate the selection of patients who would benefit the most from surgical, adjuvant or palliative treatment strategies, but may also be helpful in defining the aggressiveness of the disease and identifying patients at high-risk for tumor recurrence. The purpose of this review is to provide an overview of currently known molecular prognostic and predictive markers and their role in CCA.

Keywords: cholangiocarcinoma; biliary tract cancer; biomarker; prognosis; predictive; targeted therapy

\section{Introduction}

Cholangiocarcinoma (CCA) is a highly aggressive malignancy and the second most common primary liver tumor, accounting for three percent of all gastrointestinal malignan- 
cies [1]. The classification is based upon the anatomical site of origin, thus differentiating between intrahepatic (iCCA), perihilar (pCCA) (also called Klatskin tumor), and distal (dCCA) cholangiocarcinoma, with dCCA and pCCA being summarized as extrahepatic cholangiocarcinomas (eCCA). The most common entities are dCCA and pCCA, accounting for about $30 \%$ and $50 \%$ of all CCAs, respectively. In contrast, iCC represents only about $10 \%$ of all CCAs [2]. The anatomical boundary defining eCCA is the cystic duct, with dCCA arising distal and pCCA proximal of the junction of the cystic duct, comprising the right and left hepatic ducts up to the second order biliary branches. Tumors located above the second order bile ducts are termed iCCA [1,3,4]. Different types of CCA do not only differ in their etiology, pathophysiology, and treatment, but also possess unique biological and pathological features, providing the opportunity for individualized prognosis determination and targeted therapies.

Many CCA cases are sporadic, arising in the absence of known risk factors such as chronic biliary inflammation (e.g., in primary sclerosing cholangitis-PSC), cholestasis, hepatobiliary parasitic infections (liver flukes like Clonorchis sinensis and Opisthorchis viverrini), and liver cirrhosis (Figure 1) [1]. Furthermore, emerging evidence over the past years has suggested an important role of the gut microbiome on development of CCA, especially in patients with inflammatory bowel disease and PSC [5]. Epigenetic and environmental factors seem to have a significant impact on the development the disease, since there is a great difference in prevalence of CCA between Southeast Asia (e.g., 85 per 100,000 in Northeast Thailand) and the Western hemisphere ( $<6$ per 100,000 population). Symptoms of CCA are usually vague and arise late in already-advanced disease, resulting in median survival of less than two years from the timepoint of diagnosis. So far, surgery remains the only curative treatment option, with a 5-year survival rate ranging between 25 and $50 \%$ after surgical resection [6-11]. Due to high risk of recurrence, especially in patients with lymph node metastasis, tumor-positive resection borders, and low-grade CCA, adjuvant chemotherapy is recommended by current guidelines [12-14]. Patients with metastatic or inoperable disease are treated with systemic chemotherapy, albeit with dismal benefit [7,15-17]. Advancements in organ preservation and poor survival outcomes following surgical resection have promoted consideration of liver transplantation (LT) as a curative approach for patients suffering from pCCA and iCCA $[18,19]$. In fact, LT in patients adhering to the so-called Mayo clinic protocol, compromising neoadjuvant chemoradiation in patients with unresectable pCCA, size $<3 \mathrm{~cm}$ and without extrahepatic or lymph node metastasis, offered promising results [20]. A French multicenter randomized, intent-to-treat study (NCT02232932) comparing the 5-year survival following capecitabine-based chemoradiotherapy with subsequent LT to standard liver resection in patients suffering pCCA is ongoing [21]. In contrast to PCCA, iCCA is a contraindication in most centers worldwide due to historically poor outcome. However, recent data suggest LT as an effective treatment in highly selected patients with localized and early iCCA or patients with disease stability after neoadjuvant chemotherapy [11]. Results from a multicenter, single-arm, prospective study (NCT02878473) evaluating the 5-year survival in patients with single iCC $\leq 2 \mathrm{~cm}$ in size, liver cirrhosis, and CA $19-9 \leq 100 \mathrm{ng} / \mathrm{mL}$, undergoing LT are eagerly awaited. While the number of patients suffering from CCA continues to rise, the need for novel diagnostic strategies and therapeutic options has become of utmost clinical importance. As such, the identification of preoperatively available molecular markers of prognosis as an adjunct to traditional staging systems has emerged as a promising strategy to select patients who may benefit the most from surgical and adjuvant therapy. Furthermore, the identification of predictive markers might result in precise and effective systemic treatment. 

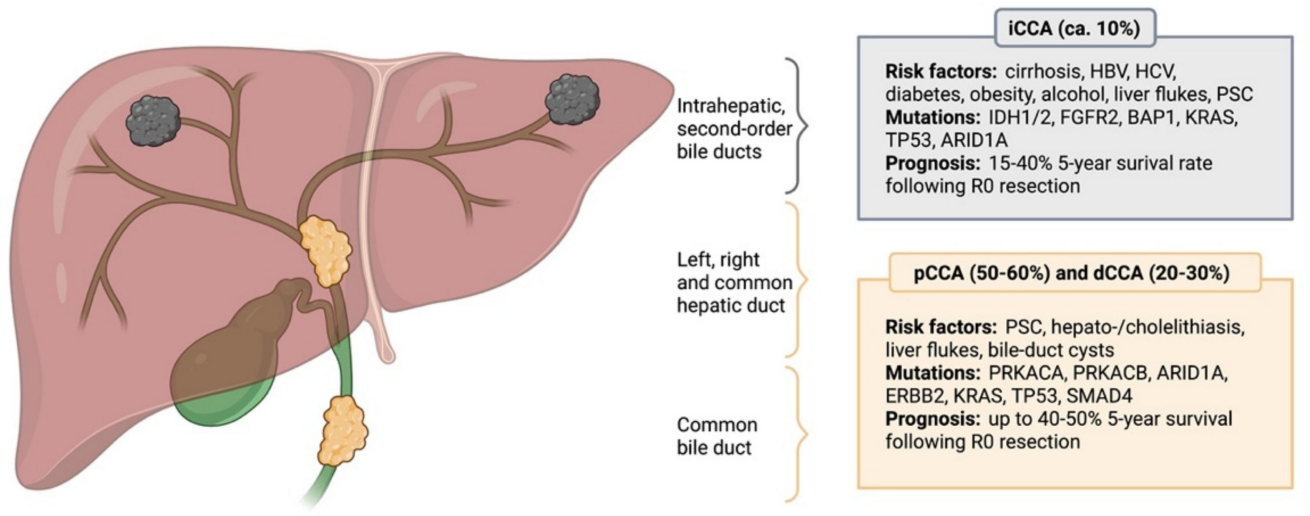

Figure 1. Anatomical classification of cholangiocarcinoma. CCA is anatomically divided into intrahepatic (iCCA), perihillar (pCCA) and distal (dCCA) cholangiocarcinoma, with pCCA and dCCA being summarized as extrahepatic cholangiocarcinoma (eCCA). Different CCA subtypes possess distinct molecular aberrations and differ in terms of their etiology, while certain risk factors and genetic mutations are not subtype-specific. The most common risk factors and prevailing genetic alterations are presented. $H B V$ : Hepatitis B virus; $H C V$ : Hepatitis C virus; PSC: Primary sclerosing cholangitis; IDH1/2: Isocitrate dehydrogenase 1/2; FGFR2: Fibroblast growth factor receptor 2; BAP1: BRCA1 associated protein 1; KRAS: Kirsten rat sarcoma virus; TP53: Tumor suppressor protein 53; ARID1A: AT-rich interactive domain-containing protein 1A; PRKACA: Protein kinase cAMP-activated catalytic subunit alpha; PRKACB: Protein kinase cAMP-activated catalytic subunit beta; ERBB2: Erb-B2 receptor tyrosine kinase 2; SMAD4: Mothers against decapentaplegic homolog 4.

\section{Biomarkers in CCA}

Biomarkers can have either prognostic or predictive value, while certain biomarkers are known to possess both. Prognostic biomarkers inform about the likelihood of certain cancer-associated events, e.g., disease-recurrence or progression of disease, and overall survival. Predictive biomarkers provide information about treatment benefit and are used to identify individuals who are more likely to have a favorable or unfavorable effect from a particular therapy compared to individuals without the biomarker [22-24]. The utility of molecular markers for clinical practice has been assessed by defining their levels of evidence, ranging from level I as the highest evidence level, obtained from high-powered, prospective, randomized controlled trials (RCT), to level V, which possess the weakest evidence and are derived from single clinical cases. Importantly, in order for a novel biomarker to be implemented into the routine clinical practice, at least level II evidence is required [25].

Different types of CCA do not only show distinct anatomical and histological features, but also possess individual molecular profiles and genetic aberrations. In this context, Nakamura et al. identified a total of 32 significantly altered genes in about $40 \%$ of cases by molecularly characterizing biliary tract cancers from 260 patients [26]. Another research group analyzed 410 cancer-associated genes in tumor samples of 195 patients and discovered genetic alterations with potential therapeutic implications in $47 \%$ these of patients [27]. The spectrum of actionable genomic targets in CCA embraces various kinases (FGFR1, FGFR2, FGFR3, PIK3CA, ALK, EGFR, ERBB2, BRAF and AKT3), oncogenes (IDH1, IDH2, CCND1, CCND3 and MDM2) and tumor-suppressor genes (BRCA1 and BRCA2) [26]. The most common genetic alterations shared between iCCA and eCCA are KRAS mutations $(15 \%-20 \%)$, TP53 mutations ( $15 \%-25 \%)$ and AT-rich interactive domain-containing protein 1A (ARID1A) mutations (approx. 20\%) [28]. Certain alterations, such as FGFR1/2 fusions or IDH1 mutations, are unique to iCCA and rarely occur in eCCA. Mutations in BRCA1 associated protein 1 (BAP1) are also enriched in iCCA and present in less than $1 \%$ of eCCA. In contrast, mutations in ERBB2 seem to be exclusive to eCCA [26,29]. An overview of common signaling pathways involved in the development and progression of CCA is displayed in Figure 2. 


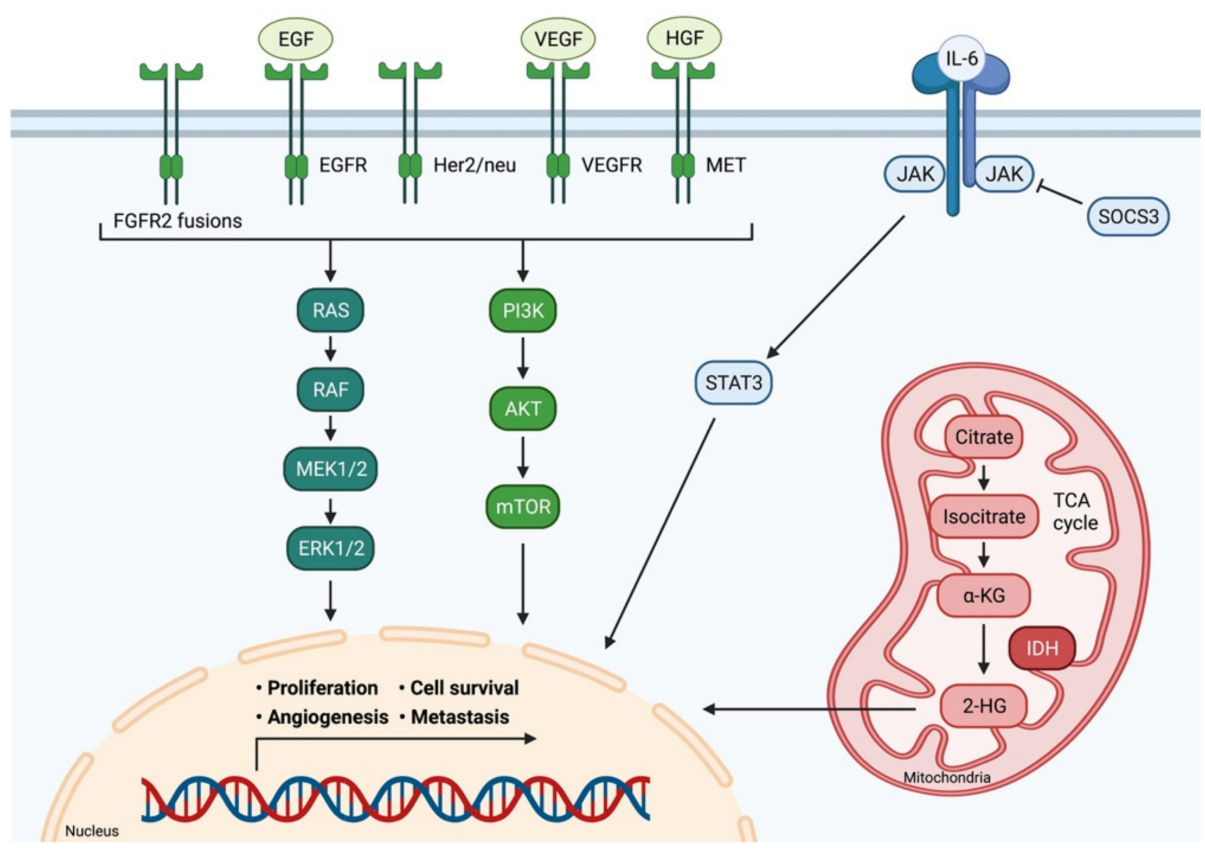

Figure 2. Signaling pathways in cholangiocarcinoma. Multiple signaling pathways are involved in the development and progression of CCA. Receptor tyrosine kinases activate the RAS-MAPK pathway and the PI3K-AKT pathway. IL-6 induces the JAK/STAT signaling pathway. Consequently, these pathways impact important cellular processes, such as cell proliferation, differentiation, survival, and angiogenesis. IDH $1 / 2$ mutations lead to the accumulation of the oncometabolite intracellular 2-hydroxyglutarate (2-HG). Adapted from [30]. FGFR2: Fibroblast growth factor receptor 2; EGF: Epidermal growth factor; EGFR: Epidermal growth factor receptor; Her2/neu: Human epidermal growth factor receptor 2; VEGF: Vascular endothelial growth factor; VEGFR: Vascular endothelial growth factor receptor; HGF: Hepatocyte growth factor; MET: C-met-encoded receptor for hepatocyte growth factor; IL-6: Interleukin-6; JAK: Janus kinase; SOCS3: Suppressor of cytokine signaling 3; STAT3: Signal transducer and activator of transcription protein; RAS: Rat sarcoma; RAF: Rat fibrosarcoma; MEK1/2: Mitogen-activated protein kinase kinase; ERK1/2: Extracellular signal-regulated kinase 1/2; PI3K: Phosphatidylinositol 3 kinase; AKT: Protein kinase B; mTOR: Mammalian target of rapamycin; $\alpha$-KG: $\alpha$-Ketoglutaric acid; 2-HG: 2- hydroxyglutarate; IDH: Isocitrate dehydrogenase; TCA cycle: Citric acid cycle.

In the following paragraphs, we will provide an overview of the most relevant biomarkers used for prognosis prediction in patients with CCA. Additionally, currently known molecular aberrations, which were identified as predictive biomarkers of treatment response, will be discussed.

\section{Prognostic Serum Biomarkers}

Prognostic markers in patients with CCA are currently based on clinical factors, such as tumor extent, existence of metastasis, surgical resection margin or histological tumor differentiation. Over the last years, various molecular markers of prognosis, obtained mainly from peripheral blood and tumor tissue, have been proposed for the detection and prediction of prognosis in CCA (Table 1).

\subsection{Serum Proteins}

So far, carbohydrate antigen (CA19-9) and carcinoembryonic antigen (CEA) are the most widely used biomarkers for diagnosis and surveillance of CCA. CA 19-9, a glycoprotein mainly produced by biliary and pancreatic duct cells, has been associated with poor prognosis, while preoperatively elevated levels of CA 19-9 proved to be a negative independent prognostic factor in CCA [31,32]. Furthermore, CA $19-9$ decline $\geq 50 \%$ under 
chemotherapy with gemcitabine correlated with improved therapy response and increased survival in patients with advanced CCA [33]. However, the sensitivity and specificity of this biomarker is $72 \%$ and $84 \%$, respectively, thus limiting its diagnostic and prognostic value [34]. CEA is a commonly used tumor marker in colorectal cancer but has evolved as a relevant biomarker in CCA as well [35]. In fact, studies have reported high variations in terms of sensitivity and specificity of CEA in patients with CCA, ranging from approximately $40 \%-80 \%$ and $50 \%-90 \%$, respectively [33,36-38]. CEA has been identified as an independent prognostic marker in CCA, especially in combination with CA 19-9 [36,38-42]. Nonetheless, the partially low sensitivity and specificity reported should be kept in mind when using this biomarker for diagnosis and surveillance of CCA. Other promising serum diagnostic and prognostic biomarkers include cytokeratin-19 fragment (CYFRA 21-1), matrix metalloproteinase-7 (MMP-7) and osteopontin. CYFRA 21-1 showed a negative correlation with one-year outcome in patients with iCCA and gallbladder carcinoma, but no association with eCCA was found [43]. Interestingly, CYFRA 21-1 and MMP-7 levels were both elevated in patients with CCA compared to those with benign biliary disease, emphasizing their putative diagnostic value [44]. The role of osteopontin, a secreted extracellular matrix glycophosphoprotein, remains inconclusive. While Loosen et al. showed that serum osteopontin levels are increased in patients with CCA and associated with impaired survival, another study demonstrated the opposite [45,46]. Although data on these biomarkers seem promising, further studies are required to validate current findings.

\subsection{Inflammatory Biomarkers}

Circulating cytokines have been associated with disease progression, tumor stage or treatment response in numerous malignancies. In the context of CCA, increased levels of interleukin-6 (IL-6) were found in patients with CCA, compared to healthy individuals, showing a rather moderate sensitivity $(73 \%)$ and specificity of $92 \%$. Furthermore, high expression of IL-6 in serum and tumor tissue, as well as marked expression of interleukin-17 (IL-17) in peritumoral cells negatively correlated with overall survival (OS) and disease-free survival (DFS) in patients who underwent surgical resection of iCCA [47].

The urokinase plasminogen activator receptor (suPAR) is an inflammatory mediator and the soluble form of the cell surface receptor UPAR (CD87). suPAR was demonstrated to be an independent prognostic biomarker in various cancer types. In terms of CCA, increased uPAR expression in tumor tissue and suPAR expression in patients' serum has been associated with impaired survival, whereas another study showed a positive correlation between uPAR expression and lymphatic invasion and metastasis, respectively [48,49]. Furthermore, elevated baseline levels of uPAR were predictive of poor survival in patients treated with palliative chemotherapy due to inoperable CCA [50].

Since a combination of two prognostic markers may improve the power of prognosis, the ratio of certain serum proteins with high diagnostic and predictive power was applied in several cancer types. As such, various ratios of myeloid and lymphatic cells have been proposed as prognostic markers in CCA. Indeed, the neutrophil-to-lymphocyte ratio, a well know prognostic factor in gastric and lung cancer, was associated with impaired survival in patients with resected CCA, as well as in those under chemotherapy due to advanced disease. Moreover, C-reactive-protein to albumin ratio negatively correlated with OS and DFS in CCA [51]. The albumin to gamma-glutamyltransferase ratio (AGR) proved to be an independent prognostic indicator for iCCA following curative resection, demonstrating improved predictive accuracy compared with the TNM staging alone [52]. Other inflammatory biomarker ratios calculated from peripheral blood measurements are still under investigation. While relatively simple to determine, these putative outcomepredicting ratios have not become part of the clinical routine yet.

\subsection{Circulating Nucleic Acids}

In recent years, circulating nucleic acids, such as cell-free DNA (cfDNA) or RNA, mostly microRNA (miRNA), have emerged as promising biomarkers for detection and 
prognosis prediction in multiple cancer types due to their abundance and stability in biofluids. In the case of CCA, the sensitivity and specificity of pooled miRNAs were calculated at up to $80 \%$ and $90 \%$, respectively, in several metanalyses [53-56]. Notably, miRNA measured in bile samples showed the highest diagnostic efficiency. Increased serum and plasma levels of miR-21 positively correlated with the TNM stage and poor survival and decreased after surgical resection of the tumor. Notably, estimation of miR-21 enabled differentiation between patients with CCA and healthy controls, however miR-21 was increased in other malignancies as well, thus limiting its specificity [57]. Further studies investigating other miRNAs are controversial. While reduced levels of miR-150 were observed in individuals with CCA, another study reported an upregulation of miR-150 in patients suffering iCCA. Remarkably, the combination of reduced miR-150 and increased CA19-9 seemed to improve the accuracy of CCA diagnosis [58]. Expression of miRNAs was further investigated in bile samples and correlated with CCA occurrence; however, their prognostic value remains inconclusive [57].

cfDNA represents a fragment of DNA which is released upon cell apoptosis or necrosis, a common process in tumorigenesis. The most appealing fact about cfDNA determination is the ability to screen for overall mutation patterns of the respective malignancy without the need for obtaining primary tumor tissue. To support these findings, plasma samples from 31 patients with CCA were screened for oncogenic mutations. The results showed that the same mutation patterns could be observed in the tumor itself [59]. Hence, cfDNA might facilitate the detection of specific genomic alterations and subsequently the establishment of effective, mutation-based therapies.

\subsection{Single-Nucleotide Polymorphisms}

Single-nucleotide polymorphisms (SNPs) are genetic modifications defined by a substitution of a single nucleotide at a specific position in the genome. Depending on the function of the affected genetic region, SNPs have been associated with clinical outcomes and cancer susceptibility in a large variety of malignancies, making them potential prognostic or therapeutic targets [60-64]. Most recently, a single-center analysis of multiple genes involved in tumor inflammation and angiogenesis revealed CXCR1 (interleukine8-receptor alpha-IL-8RA) $+860 \mathrm{C}>\mathrm{G}$ heterozygous polymorphism to be an independent prognostic factor for DFS, cancer-specific survival and OS in patients with pCCA [65]. Further studies have linked SNPs to CCA. The G protein subunit- $\beta 3$ (GNB3) 825 C>T polymorphism was associated with longer OS in patients with eCCA [66]. Other variants, such as the enhancer of zeste homolog 2 (EZH2), nuclear factor (erythroid-derived 2)-like 2 (NRF2), x-ray repair cross-complementing group (XRCC1), ATP binding cassette subfamily C member 2 (ABCB2), ATPase Phospholipid Transporting 8B1 (ATP8B1), natural killer cell receptor G2D (NKG2D), and alpha1-antitrypsin ( $\alpha 1 \mathrm{AT})$ deficiency $Z$ heterozygosity, have been linked to increased risk of CCA or associated with the outcome of patients with bile duct tumors $[64,67,68]$. Nevertheless, biomarker-embedded clinical trials and validation in independent cohorts of patients are required to confirm these preliminary findings.

\subsection{Other Biomarkers with Potentially Prognostic Value}

Circulating tumor cells (CTC), various metabolites found in bile, blood, or urine, as well as extracellular vesicles represent some of other biomarkers currently evaluated for diagnosis and outcome prediction in patients with CCA [69]. While metabolites and extracellular vesicles have been investigated mostly for diagnostic purpose and differentiation between CCA and other hepatic malignancies or non-malignant biliary diseases, CTC have shown an association with DFS and OS in numerous malignancies. However, the number of studies suggesting that CTCs may have an impact on clinical outcome in CCA are scarce [57].

Taken together, numerous molecular markers of prognosis in CCA with promising results from clinical studies have been identified over recent years. Before implementation into clinical routine, larger patient cohorts and biomarker-embedded clinical trials are 
needed. Furthermore, novel technologies enabling the measurement of cf-DNA or miRNAs, will facilitate the detection of novel biomarkers in the future. Even though determination of CA19-9 and CEA has certain limitations, they remain the most frequently used and best evaluated serum biomarkers in CCA.

\section{Prognostic Tumor Tissue Biomarkers}

Biomarkers from tumor tissue present a valuable source of potential factors for outcome prediction in terms of both survival and treatment response, or individualized therapies in patients suffering CCA (Table 2). In fact, CCA was described as a highly genomic heterogeneous malignancy, with most of the genetic alterations being related to DNA repair mechanism, chromatin remodeling or cancer cell proliferation and growth [57]. While some mutations are specific to either iCCA or eCCA, others are found in tumor tissue irrespective of the anatomical localization. The latter include mutations in the KRAS proto-oncogene (15-22\%), TP53 tumor suppressor gene (25-40\%), ARID1A chromatin remodeling complex (12-18\%), and BRCA1/2 (3-5\%). Mutations in KRAS and TP53 have been associated with impaired outcome and tumor recurrence following surgical resection of CCA, thus highlighting their prognostic value [70]. The role of ARID1A as a prognostic marker remains inconclusive since it has been described as both an oncogene and tumor-suppressor gene. Inactivation of ARID1A correlated with tumor metastasis and was common in liver fluke-associated CCA [71]. Another study confirmed the prognostic role of ARID1A by showing a correlation between low ARID1A expression and impaired outcome in patients with iCCA [72]. In contrast, increased expression of ARID1A was associated with a higher risk of mortality and disease recurrence in patients with iCCA [73]. In a large metanalysis, including 4,126 patients from 73 studies, that analyzed 77 known biomarkers, EGFR, MUC1, MUC4, fascin, and p27 showed an association with OS of patients suffering from CCA [74]. Another metanalysis assessed prognostic biomarkers associated with OS in patients with eCCA in a univariate analysis. While six markers (VEGF, COX-2, GLUT-1, cyclin D1, fascin, and Ki-67) correlated with impaired survival, p16, p27, and E-Cadherin had positive prognostic effects [75]. Moreover, the analysis of 53 patients with surgical tumor resection due to CCA revealed 39 transcriptomic prognostic biomarkers. Interestingly, all of them showed a relation with T-cell activation and immune response. For instance, the expression levels of cytotoxic T-lymphocyte antigen 4 (CTL4) and forkhead box P3 (FOXP3) correlated with recurrence-free survival [76].

\subsection{Cell Surface Molecules}

Several cell surface molecules are known to have significant impact on cancer progression by regulating cell motility and transcellular signaling. As such, expression of CD155, an immunoglobulin-like transmembrane glycoprotein, was associated with shorter DFS and OS in patients suffering CCA. Upregulation of CD155 correlated with histological grading, lymph node metastasis, expression of vascular endothelial growth factor (VEGF), and microvascular density, and was suggested as an independent prognostic marker for CCA [77]. High expression of CD44 correlated with significantly shorter OS compared to low intratumoral expression of CD44 in patients with liver fluke-associated CCA [78]. Furthermore, CD55 and CD97 showed an association with poor histological grading, lymph node metastasis, venous invasion, and shorter OS, while CD98 was proposed as an independent prognostic factor in CCA [79].

\subsection{Signaling Molecules}

Diverse signaling molecules, mainly cytokines and intracellular signaling molecules, are directly involved in carcinogenesis and have been associated with patients' outcome in multiple cancer types. As such, increased levels of IL-6 in tumor tissue and IL-17 in peritumoral cells correlated with impaired OS and DFS in patients with iCCA. Furthermore, multivariate analysis revealed that IL6 and peritumoral IL17 are independent prognostic factors for DFS, while preoperatively increased levels of IL-6 in serum were associated 
with significantly reduced DFS [47]. Suppressor of cytokine signaling 3 (SOCS3) is an antagonist of the JAK/STAT pathway, thus playing an integral role in shaping the inflammatory environment and tumorigenesis in CCA. The expression of SOCS3 was significantly downregulated in tumor tissue of patients with CCA, while the upstream regulator tumor necrosis factor $\alpha$-induced protein 3 (TNFAIP3 or A20) was increased. Notably, patients with low intratumoral expression of SOCS3 and high expression of A20 showed a dramatically reduced OS rate. Moreover, both proteins were associated with lymph node metastasis and postoperative disease recurrence, thereby suggesting their role as prognostic markers in CCA [80].

Ring finger protein 43 (RNF43), which has been described as both an oncogene and tumorsuppressor gene, was downregulated in tumor tissue of patients with iCCA and correlated with poor prognosis. Furthermore, RNF43 was shown to be an independent prognostic factor in uni- and multivariate analysis [81].

LIM and SH3 protein 1 (LASP-1) is a focal adhesion protein, known to play a key role in cell migration, invasion, and proliferation in a wide variety of tumors. Analysis of human CCA tissue samples revealed that LASP-1 was markedly overexpressed in tumor compared to healthy tissue. Moreover, expression of LASP-1 positively correlated with tumor size, poor histological differentiation, lymph node metastasis, advanced TNM stage, and poor prognosis in CCA patients. In contrast, downregulation of LASP-1 resulted in cancer cell apoptosis and suppressed cell migration, invasion, and proliferation in vitro [82].

Similarly, the expression of B7-H4, which is a member of the B7 superfamily of ligands and regulator of $\mathrm{T}$ cell-mediated antitumor immune response, was upregulated in cancer tissue in approximately $50 \%$ of cases in a cohort of 137 patients suffering from CCA and was associated with poor histological differentiation, lymph node metastasis, staging, reduced OS, and early recurrence of tumor. Additionally, B7-H4 suppressed the peritumoral infiltration of CD8+ cytotoxic T lymphocytes [83]. Hepatoma-derived growth factor (HDGF) is another biomarker that has been associated with poor outcome and tumor progression in patients suffering CCA [84]. High expression of Ki-67, a well-known proliferation marker, and p73 was associated with shorter OS of pCCA patients, while Ki-67 correlated with tumor stage [85].

Induction of epithelial mesenchymal transition (EMT) results in increased cancer cell proliferation and metastasis. Indeed, SOX4 transcription factor, a member of the SOX (SRY-related HMG-box) family, has been shown to promote EMT in vitro, while SOX4 overexpression in tumor tissue indicated poor prognosis in patients with iCCA [86]. Moreover, elevated serum level of nardilysin (N-arginine dibasic convertase, NRDC), a soluble cytosolic protein, correlated with increased NRDC mRNA expression in tumor tissue and EMT-inducing transcription factors, and was associated with shorter OS and DFS in patients with iCCA [87].

\subsection{Mucins}

Mucins (MUC) are heavily O-glycosylated proteins, mainly expressed by ductal and glandular epithelial tissues. Vast production of mucus is frequently found in various carcinomas and has been described in CCA multiple times. In this context, MUC5AC was aberrantly expressed in tumor tissue and associated with larger tumor size and advanced stage in liver fluke-associated CCA [88]. Another study showed an association between MUC5AC expression in iCCA tissue and lymph node metastasis in patients who underwent curative-intent hepatectomy. Additionally, increased MUC5AC expression was identified as an independent prognostic marker of poor survival in patients with iCCA [89].

\subsection{Tumor Stroma and Microenvironment}

The tumor microenvironment plays a crucial role in shaping the growth, proliferation, and metastasis of malignant cells. Thus, certain molecules localized in tumoral stroma might be used as prognostic markers. Indeed, overexpression of epithelial cell adhesion molecule (EpCAM) in the stroma of ICC proved to be an independent risk factor for OS and 
DFS. Besides expression in iCCA tissue, overexpression of EpCAM in nontumor fibrous liver tissue correlated with reduced DFS as well [90]. Furthermore, high expression of Lysyl oxidase-like 2 (LOXL2), a matrix-remodeling enzyme that has already been associated with metastasis in hepatocellular carcinoma (HCC), in peritumoral stroma proved to be an independent prognostic factor of worse OS and DFS in patients with iCCA [91]. The metalloproteinases (MMP) are enzymes that degrade extracellular matrices, thus facilitating tumor cell progression and metastasis. MMP-9 and MMP-11 were markedly expressed in CCA tissue, and their expression correlated with decreased OS [92,93]. Tissue expression of MMP-9 was associated with IL-8 tissue expression, while the latter proved to be an independent prognostic factor of OS in patients with CCA [94].

\subsection{Non-Coding RNA}

The emerging role of serum-derived non-coding RNAs as prognostic biomarkers has been described in the previous section. Similarly, non-coding RNA, mostly microRNA (miRNA), small interfering RNA (siRNA), and long non-coding RNA (lncRNA), can be measured in tumor tissue. In this context, different studies reported an overexpression of lncRNA H19 and lncRNA-PANDRA in CCA tissue, as well as a significant correlation with tumor progression, TNM staging and OS of patients. Accordingly, in vitro analysis demonstrated the involvement of both RNAs in cell growth and proliferation, EMT and anti-apoptosis $[95,96]$. Hence, lncRNA H19 and PANDRA may serve as poor prognostic markers for CCA.

Using a custom microarray, the expression levels of three miRNAs, miR-675-5p, miR652-3p and miR-338-3p, were identified in CCA tissue and strongly correlated with the prognosis of patients with iCCA. Risk scores, defined by using regression coefficients risk, revealed significantly shorter OS and DFS medians in patients with high-risk scores compared to those with low-risk scores. This three-miRNA signature was marked as an independent prognostic predictor for iCCA [97]. Upregulation of tissue miR-29a was suggested as a beneficial prognostic marker for CCA [98].

In conclusion, tumor tissue biomarkers may be of particular value for resected CCA, as they can have both prognostic (e.g., KRAS, TP53), as well as predictive (e.g., IDH1/2, FGFR2) implications by predicting the individual patient's prognosis and response to targeted therapies. The major drawback remains the necessity of an invasive procedure for tissue sample collection, especially in patients with primary unresectable disease. Alternatively, a preliminary study by Ikeno et al. suggested non-invasive assessment of tumor metabolic activity by ${ }^{18} \mathrm{~F}$-fluorodeoxyglucose positron emission tomography $\left({ }^{18} \mathrm{~F}-\mathrm{FDG}\right.$-PET) to be associated with impaired survival in patients with iCCA and KRAS mutations [99]. In comparison, serum biomarkers are less invasive to obtain, thus being more suitable for diagnosis and monitoring of disease recurrence. The ideal combination of both biomarker types, as well as sampling timepoints are yet to defined. The detection of genetic aberrations in CCA tissue renders the development of custom and more effective therapies possible and will be discussed in the following paragraphs.

\section{Predictive Biomarkers of Treatment Response and Novel Therapeutic Strategies}

While patients with metastatic or locally advanced non-resectable disease are treated to with palliative chemotherapy, surgical resection with adjuvant chemotherapy represents the gold standard in patients with resectable CCA. According to current guidelines, first-line adjuvant chemotherapy should be conducted with capecitabin, whereas gemcitabin/cisplatin is recommended for patients with advanced disease [100-102]. However, the survival rates in both patient groups remain poor, thus prompting the development of targeted and more effective therapies (Supplementary Tables S1-S7). CCA is marked by a high rate of genomic alterations. Even though the most common ones, such as KRAS, TP53 and ARID1A are not easily druggable, $>40 \%$ of CCA still bear a targetable genetic alteration [28]. 


\subsection{Fibroblast Growth Factor Receptor}

Fibroblast growth factor receptor 2 (FGFR2) fusions are unique to iCCA and represent one of the main druggable targets. Fibroblast growth factor receptor tyrosine kinases (FGFR) play a key role in activating important signaling pathways, such as RAS-RAFMEK-ERK and PI3K-AKT-mTOR cascade, thus regulating cellular growth, survival, and differentiation $[103,104]$. Although the prognostic value of FGFR2 remains controversial, clinical studies evaluating FGFR inhibitors as targeted therapy for patients with advanced CCA show promising results [103,105-111]. Mazzaferro et al. published in 2019 a multicenter, phase I/II, open-label study exploring safety and effectivity of derazantinib, a pan-FGFR inhibitor, in patients with FGFR2 gen fusion-positive iCCA [112]. With an overall response rate of $20.7 \%$ and a disease control rate of $82.8 \%$, derazantinib offered a promising anti-tumor activity, resulting in initiation of a larger study for this patient population (NCT03230318) [112]. Based on a promising phase II trial reporting a 14.8\% response rate with a 75.4\% disease control rate (NCT02150967; [113-115]), the selective FGFR1-3 inhibitor infigratinib is currently evaluated in comparison to gemcitabine and cisplatin in patients with advanced or metastatic CCA and FGFR2 gene fusion in a running phase III RCT (NCT03773302) [116]. Futibatinib and pemigatinib are further selective FGFR kinase inhibitors under current investigation in phase III RCT (NCT04093362 [117]; NCT03656536 [118]).

\subsection{C-met-Encoded Receptor for Hepatocyte Growth Factor}

Another signaling pathway, impacting cell proliferation, motility, and sensitivity to apoptotic cell death, that may be impaired in CCA, is the c-met-encoded receptor (MET) for hepatocyte growth factor signaling pathway [105]. MET is a heterodimeric tyrosine kinase transmembrane protein and receptor of the hepatocyte growth factor [119]. Overexpression of MET occurs in up to $60 \%$ of iCCA, whereas mutations in MET axis can be detected in $7 \%$ of iCCA [105]. In 2013 Pant et al. examined the combination of tivantinib, an inhibitor of the c-MET tyrosine kinase, and gemcitabine in patients with solid tumors, among them CCA, showing promising results in terms of antitumor activity [120]. In 2017 the research group Goyal et al. demonstrated in a phase II study the limited activity and toxicity of cabozantinib, another multikinase inhibitor targeting MET and vascular endothelial growth factor receptor 2 (VEGFR2) [121]. Further studies are still ongoing (NCT02496208, NCT02711553).

\subsection{Tyrosine Kinases}

Tyrosine kinases are enzymes responsible for the activation of signal transduction cascades through phosphorylation of participative proteins, a step that is inhibited by tyrosine kinase inhibitors. Representative members of the tyrosine kinase family are HER2/neu, VEGFR, platelet-derived growth factor receptor (PDGFR), and FGFR2, all playing an important role in tumorigenesis, cancer progression, and survival. In this context, recent studies have highlighted their use as targeted therapies in treatment of CCA [122]. EGFR is a transmembrane protein of the ErbB tyrosine kinase receptor family, compromising four distinct membrane receptors: EGFR (ERBB1), HER2/neu (ERBB2), ERBB3, and ERBB4 [123]. Overexpression of EGFR and HER2/neu has been detected in up to 30\% of iCCA, resulting in promoted tumor cell proliferation, migration, and angiogenesis [123]. In fact, multivariate analysis showed that EGFR expression was a significant prognostic factor and risk factor for tumor recurrence in CCA [124]. Consequently, one could imagine that inhibition of EGFR tyrosine kinase activity might results in decreased progression of CCA, thus making it a promising therapeutical approach. Drugs targeting EGFR can be divided in tyrosine kinase inhibitors, like gefitinib and erlotinib, and monoclonal antibodies, such as cetuximab and panitumumab [125]. Various HER2/neu and EGFR inhibitors are currently being studied, either as single-agents, in addition to established chemotherapy or in combination with other targeted agents, such as the VEGF inhibitor bevacizumab [126-128]. Even though initial trials investigating the use of anti-EGFR and anti-HER2/neu inhibitors in patients 
with advanced CCA were promising [128,129], data from subsequent phase II RCTs were disappointing. In fact, neither the application of lapatinib (EGFR and HER2/neu double inhibitor), panitumumab (anti-EGFR antibody), nor cetuximab (anti-EGFR inhibitor), as monotherapy or in addition to traditional chemotherapy (gemcitabine and oxaliplatin), significantly increased the OS or progression free survival (PFS) [130-134]. Interestingly, the addition of erlotinib, a drug targeting EGFR by tyrosinase kinase inhibition, to chemotherapy with gemcitabine and oxaliplatin significantly prolonged PFS in a subgroup of patients suffering from CCA [135]. Furthermore, the combination of erlotinib with the VEGF antibody bevacizumab showed promising results for treatment of advanced biliary cancer in a multicenter phase II clinical trial [127]. HER2/neu overexpression was found to be higher in eCCA than in iCC [136]. However, studies investigating the use of HER2/neu antibodies, such as pertuzumab and trastuzumab, did not provide convincing results in terms of oncological outcome $[137,138]$. Additional studies investigating targeted therapies directed at HER2/neu or the use of multikinase inhibitors are ongoing.

\subsection{Angiogenesis}

VEGF and its receptors play a pivotal role in tumor angiogenesis. In fact, overexpression of VEGF has been reported in up to $50 \%$ of iCCA and $60 \%$ of eCCA [124]. However, data on antitumorigenic effects of several VEGF inhibitors, such as bevacizumab and sorafenib, were rather disappointing [139-145]. Recently, the multikinase inhibitor regorafenib showed promising efficiency in two phase II trials [146,147]. Based on these encouraging results, Demols et al. conducted a multicenter phase II RCT for patients with nonresectable or metastatic biliary tract cancer and progression on first-line chemotherapy, revealing a significant improvement of PFS and tumor control in patients treated with regorafenib [148]. The VEGFR2 inhibitor apatinib is evaluated in an ongoing RCT as well (NCT03609489).

\subsection{Isocitrate Dehydrogenase- 1 and -2}

Isocitrate Dehydrogenase 1 or 2 (IDH) catalytic site mutations exclusively occur in iCCA with a percentage of $18-30 \%$ [26,29]. IDH mutations contribute to accumulation of oncometabolite intracellular 2-hydroxyglutarate (2-HG), which in turn disrupts several regulatory cellular pathways that are relevant for epigenetic remodeling and DNA repair $[30,149,150]$. Elevated levels of circulating 2-HG have been measured in IDH1/2 mutant CCA patients, suggesting the role of 2-HG as a surrogate biomarker of IDH mutation status, tumor burden or treatment response [151]. Although there are data proclaiming that IDH mutations do not have any prognostic or therapeutic significance $[2,29,110]$, recent results demonstrated IDH as a possible target for specific therapy of iCCA [150]. In this context, AG-120 (ivosidenib) is known to inhibit IDH1, whereas AG-221 (enasidenib) inhibits IDH2 [105,149]. In 2020, Abou-Alfa et al. published a multicenter phase III RCT including CCA patients with mutated IDH1 and disease progression upon standard chemotherapy, who were randomly assigned to ivodesinib or placebo treatment. Treatment with ivosidenib significantly improved PFS in this population, while effects on overall survival remain unclear. The optimal use will be explored in future trials [150].

\subsection{KRAS}

Mutations of KRAS and aberrant activation of KRAS signaling pathways occur in up to $40 \%$ of CCA, with $42 \%$ of mutations appearing in eCCA and $22 \%$ in iCCA $[105,152]$. Currently, KRAS cannot be targeted directly, but rather through inhibition of downstream PI3KAKT-mTOR and Raf-MEK-ERK pathways, both known to play an important role in cell proliferation, growth and angiogenesis. In 2011, Tanios et al. published a multi-institutional phase II study about the MEK 1/2 inhibitor selumetinib as a treatment for patients suffering from metastatic biliary cancer and demonstrated selumetinib as a well-tolerated drug in combination with current treatment strategies [153]. Furthermore, Kim et al. recently started the first prospective randomized trial on MEK inhibitor trametinib in comparison 
to chemotherapy with 5-fluorouracil or capecitabine in refractory advanced biliary cancer. However, the study had to be paused because of a lack of clinical activity of trametinib therapy [152]. The combination of trametinib with dabrafenib, a specific BRAF inhibitor, resulted in an overall response rate (ORR) of 47\% [154]. Another study investigating the effect of dabrafenib and trametinib in patients with solid tumors is ongoing (NCT02465060). Recent trials evaluating the combination of two KRAS pathway inhibitors offer some promising results $[109,155]$.

\subsection{Immunotherapy}

Inflammation and subsequent activation of the immune system play an important role in carcinogenesis and development of multiple tumors. As such, tumor cell-mediated upregulation of immune checkpoint molecules, e.g., programmed cell death protein 1 (PD-1), results in suppressed immune reaction, facilitating the survival and progression of tumor cells. In fact, the PD-1 antibody pembrolizumab has recently been approved for treatment of unresectable or metastatic microsatellite instability (MSI) high or deficient solid tumors. MSI develops upon loss of DNA mismatch repair mechanism, resulting in stronger immune response and increased expression of PD-1 ligand (PD-L1). While the role of MSI in CCA remains inconclusive, a phase II trial of pembrolizumab efficacy in MMR-deficient tumors demonstrated a 100\% disease control rate (DCR) with one complete response and three stable diseases in four patients with CCA [156]. The results of the KEYNOTE-028 phase 1b trial (NCT02054808) revealed the safety and efficacy of pembrolizumab in patients with PD-L1-positive advanced biliary tract cancer, while results from the KEYNOTE158 phase II trial showed a 40.9\% ORR in a subset of 22 patients with MSI high CCA treated by pembrolizumab [157]. Recently the TOPAZ-1 study was able to demonstrate a clinical meaningful OS benefit by adding durvalumab, a PD-L1 inhibitor, to a standard chemotherapy consisting of gemcitabine plus cisplatin (Astra-Zeneca press release October 25, 2021). Further phase-III trials (e.g., Keynote-966, NCT04003636) investigating the role of immunotherapy in CCA are ongoing.

\section{Conclusions}

Cholangiocarcinoma is an anatomically distinct and genetically heterogeneous tumor, with rising incidence worldwide, dismal prognosis and highly limited therapy options. The vast spectrum of genomic alterations differs greatly between each CCA subtype and offers the opportunity for development of prognostic and predictive biomarkers, as well as novel therapeutic strategies. Preoperative identification of prognostic biomarkers may help to identify patients who would profit the most from radical surgical resection, while preventing the risk of postoperative complications and chemotherapy delay. Furthermore, serum and tissue biomarkers could help to identify the subgroup of patients with high recurrence risk, thus necessitating closer follow-up or prolonged chemotherapy regimen. Although numerous options have been developed over the last years, including miRNAs, lncRNAs, SNPs and various signaling molecules from both patients' serum and tumor tissue, CA19-9 and CEA remain the most applied prognostic biomarkers. In either case, palliative or curative intent, development of custom and patient-directed therapies based on unique genetic alterations will increase the therapeutic effectiveness and consecutively patients' survival rates. So far, emerging targeted therapies with promising effect include FGFR inhibitors and IDH1/2 inhibitors, as well as immunotherapies. While several other biomarkers and clinical studies have shown promising results, validation in larger patient cohorts and international trials is necessary and has already been initiated to a certain extent. Over the next years, results from multicentric RCTs may fundamentally impact the diagnostic and therapeutic management of CCA and will hopefully improve patient outcomes. 
Table 1. Serum biomarkers associated with prognosis in CCA.

\begin{tabular}{|c|c|c|c|c|}
\hline Name & Occurrence & Expression & $\begin{array}{c}\text { Associated } \\
\text { Prognostic Value }\end{array}$ & Reference \\
\hline \multicolumn{5}{|c|}{ Proteins/Cytokines } \\
\hline CA19-9 & CCA (all subtypes) & Increased & OS & [31-34] \\
\hline CEA & $\begin{array}{l}\text { mostly iCCA, but also } \\
\text { all CCA subtypes }\end{array}$ & Increased & OS & {$[36,38-42]$} \\
\hline CYFRA & $\begin{array}{l}\text { iCCA, gallbladder } \\
\text { cancer }\end{array}$ & Increased & OS & {$[43,158]$} \\
\hline & CCA (all subtypes) & Increased & OS & {$[45]$} \\
\hline Osteopontin & iCCA & $\begin{array}{l}\text { Low level of circulating } \\
\text { osteopontin/volume; Decreased } \\
\text { expression in tumor tissue }\end{array}$ & OS & [46] \\
\hline $\begin{array}{l}\text { Urokinase plasminogen } \\
\text { activator receptor (uPAR) }\end{array}$ & CCA (all subtypes) & $\begin{array}{c}\text { Elevated serum levels; Increased } \\
\text { expression in tumor tissue }\end{array}$ & OS & [48] \\
\hline 2-hydroxyglutarate (2-HG) & iCCA & Elevated serum levels & $\begin{array}{l}\text { IDH1/2 mutation } \\
\text { status, tumor burden }\end{array}$ & [151] \\
\hline Nardilysin (NRDC) & iCCA & $\begin{array}{l}\text { Elevated serum levels and mRNA } \\
\text { expression in tumor tissue }\end{array}$ & OS, DFS & [87] \\
\hline IL-6 & iCCA & Elevated serum levels & DFS & [47] \\
\hline \multicolumn{5}{|c|}{ Circulating Nucleic Acids } \\
\hline $\operatorname{miR}-21$ & CCA (all subtypes) & Elevated serum levels & $\begin{array}{l}\text { OS, clinical staging, } \\
\text { metastasis }\end{array}$ & [159] \\
\hline miR-192 & $\begin{array}{l}\text { Liver fluke-associated } \\
\text { CCA }\end{array}$ & Elevated serum levels & $\begin{array}{l}\text { OS, lymph node } \\
\text { metastasis }\end{array}$ & [160] \\
\hline miR-106a & CCA & Decreased serum levels & $\begin{array}{l}\text { OS, lymph node } \\
\text { metastasis }\end{array}$ & [161] \\
\hline miR-26a & CCA & Elevated serum levels & $\begin{array}{c}\text { OS, clinical stage, } \\
\text { metastasis, } \\
\text { differentiation status }\end{array}$ & [162] \\
\hline $\begin{array}{l}\text { Panel (miR-29, miR-122, } \\
\text { miR-155, miR-192 }\end{array}$ & CCA & Elevated serum levels & OS & [56] \\
\hline \multicolumn{5}{|c|}{ Single-Nucleotide Polymorphisms (SNPs) } \\
\hline CXCR1 +860 C>G & pCCA & Heterozygous polymorphism & OS, DFS & {$[65]$} \\
\hline $\begin{array}{l}\text { G protein subunit- } \beta 3 \\
\text { (GNB3) } 825 \mathrm{C}>\mathrm{T}\end{array}$ & eCCA & Heterozygous polymorphism & OS & [66] \\
\hline EZH2 rs887569 TT genotype & CCA & Homozygous polymorphism & OS & [163] \\
\hline $\begin{array}{c}\text { NRF2 rs6726395 GG } \\
\text { genotype }\end{array}$ & CCA & Homozygous polymorphism & OS & [164] \\
\hline
\end{tabular}


Table 2. Tumor tissue biomarkers associated with prognosis in CCA.

\begin{tabular}{|c|c|c|c|c|}
\hline Name & Occurrence & Expression & Associated Prognostic Value & Reference \\
\hline \multicolumn{5}{|c|}{ Cell Surface Molecules } \\
\hline CD 155 & CCA & Increased & $\begin{array}{l}\text { OS, DFS, histological grading, } \\
\text { lymph node metastasis }\end{array}$ & [77] \\
\hline CD44 & $\begin{array}{l}\text { Liver fluke-associated } \\
\text { CCA }\end{array}$ & Increased & OS & [78] \\
\hline CD55, CD97 & iCCA & Increased & $\begin{array}{l}\text { OS, histological grading, lymph } \\
\text { node metastasis, venous invasion }\end{array}$ & [165] \\
\hline CD98 & CCA & Increased & OS & [166] \\
\hline \multicolumn{5}{|c|}{ Signaling Molecules, Growth Pathways, Angiogenesis } \\
\hline IL-6 & iCCA & Increased & OS, DFS & [47] \\
\hline IL-17 & iCCA & $\begin{array}{l}\text { Increased peritumoral } \\
\text { expression }\end{array}$ & OS, DFS & [47] \\
\hline SOCS3 & CCA & $\begin{array}{l}\text { Low intratumoral } \\
\text { expression }\end{array}$ & $\begin{array}{l}\text { OS, lymph node metastasis, } \\
\text { postoperative disease recurrence }\end{array}$ & [80] \\
\hline $\begin{array}{l}\text { Tumor necrosis factor } \\
\alpha \text {-induced protein } 3 \\
\text { (TNFAIP3 or A20) }\end{array}$ & CCA & $\begin{array}{l}\text { Increased intratumoral } \\
\text { expression }\end{array}$ & $\begin{array}{l}\text { OS, lymph node metastasis, } \\
\text { postoperative disease recurrence }\end{array}$ & [80] \\
\hline RNF43 & iCCA & $\begin{array}{l}\text { Low intratumoral } \\
\text { expression }\end{array}$ & OS & [81] \\
\hline $\begin{array}{l}\text { LIM and SH3 protein } 1 \\
\text { (LASP-1) }\end{array}$ & CCA & $\begin{array}{l}\text { Increased intratumoral } \\
\text { expression }\end{array}$ & $\begin{array}{l}\text { OS, tumor size, histological } \\
\text { differentiation, lymph node } \\
\text { metastasis, TNM stage }\end{array}$ & [82] \\
\hline B7-H4 & CCA & Increased & $\begin{array}{l}\text { OS, histological differentiation, } \\
\text { lymph node metastasis, staging, } \\
\text { early recurrence of tumor }\end{array}$ & [83] \\
\hline $\begin{array}{l}\text { Hepatoma-derived } \\
\text { growth factor (HDGF) }\end{array}$ & iCCA & Increased & $\begin{array}{l}\text { OS, lymph node metastasis, TNM } \\
\text { stage }\end{array}$ & [84] \\
\hline Ki-67, p73 & $\mathrm{pCCA}$ & Increased & OS, TNM stage & [85] \\
\hline $\begin{array}{l}\text { Sex-determining region } \\
\text { Y-box } 4 \text { (SOX4) }\end{array}$ & iCCA & Increased & OS & [86] \\
\hline $\begin{array}{l}\text { Sex-determining region } \\
\text { Y-box } 9 \text { (SOX9) }\end{array}$ & iCCA & Increased & OS & [86] \\
\hline KRAS & CCA & Increased & OS & [167] \\
\hline TP53 & $\mathrm{CCA}$ & Increased & OS & [167] \\
\hline \multirow{2}{*}{ ARID1A } & $\begin{array}{c}\text { CCA, mostly } \\
\text { fluke-associated iCCA }\end{array}$ & Decreased & OS & {$[71,72]$} \\
\hline & iCCA & Increased & OS, recurrence rate & [73] \\
\hline $\begin{array}{l}\text { EGFR, MUC1, MUC4, } \\
\text { fascin }\end{array}$ & CCA & Increased & OS & $\begin{array}{l}\text { Metanalysis } \\
\text { by [74] }\end{array}$ \\
\hline $\begin{array}{l}\text { VEGF, COX-2, GLUT-1, } \\
\text { cyclin D1, Ki67 }\end{array}$ & eCCA & Increased & OS & $\begin{array}{l}\text { Metanalysis } \\
\text { by [75] }\end{array}$ \\
\hline p16, p27, E-cadherin & eCCA & Increased & OS & $\begin{array}{l}\text { Metanalysis } \\
\text { by [75] }\end{array}$ \\
\hline c-MET & CCA & Increased & OS, DFS & [168] \\
\hline DKK1 & iCCA, pCCA & Increased & OS, lymph-node metastasis & {$[169,170]$} \\
\hline
\end{tabular}


Table 2. Cont.

\begin{tabular}{|c|c|c|c|c|}
\hline Name & Occurrence & Expression & Associated Prognostic Value & Reference \\
\hline \multirow[b]{2}{*}{ BAP1 } & \multirow[b]{2}{*}{ CCA } & Retained expression & OS, DFS & \multirow[b]{2}{*}[25,169,170]{} \\
\hline & & Loss of expression & $\begin{array}{l}\text { Trend towards improved OS, } \\
\text { histological differentiation, } \\
\text { lymph-node metastasis }\end{array}$ & \\
\hline PBRM1 & CCA & Retained expression & OS, DFS & {$[29,171]$} \\
\hline \multicolumn{5}{|c|}{ Mucins } \\
\hline MUC5AC & $\begin{array}{c}\text { Liver fluke-associated } \\
\text { iCCA, iCCA }\end{array}$ & Increased & $\begin{array}{l}\text { OS, lymph node metastasis, TNM } \\
\text { stage, tumor size }\end{array}$ & {$[88,89]$} \\
\hline MUC4 & CCA & Increased & OS & [172] \\
\hline MUC16 & iCCA & Increased & OS & [173] \\
\hline \multicolumn{5}{|c|}{ Tumor Stroma and Microenvironment } \\
\hline $\begin{array}{l}\text { Epithelial cell adhesion } \\
\text { molecule (EpCAM) }\end{array}$ & iCCA & $\begin{array}{l}\text { Increased expression in } \\
\text { peritumoral stroma }\end{array}$ & OS, DFS & [90] \\
\hline $\begin{array}{l}\text { Lysil oxidase-like } 2 \\
\text { (LOXL2) }\end{array}$ & iCCA & $\begin{array}{l}\text { Increased expression in } \\
\text { peritumoral stroma }\end{array}$ & OS, DFS & [91] \\
\hline $\begin{array}{c}\text { Matrix } \\
\text { metalloproteinase }-9 \\
(\text { MMP-9) }\end{array}$ & pCCA & $\begin{array}{l}\text { Increased tissue } \\
\text { expression }\end{array}$ & OS & [92] \\
\hline $\begin{array}{c}\text { Matrix } \\
\text { metalloproteinase }-11 \\
(\text { MMP-11) }\end{array}$ & CCA & $\begin{array}{l}\text { Increased tissue } \\
\text { expression }\end{array}$ & OS & [93] \\
\hline \multicolumn{5}{|c|}{ Non-Coding RNA } \\
\hline lncRNA H19 & CCA & $\begin{array}{l}\text { Increased tissue } \\
\text { expression }\end{array}$ & OS, DFS, tumor size, TNM stage & [95] \\
\hline lncRNA-PANDRA & CCA & $\begin{array}{l}\text { Increased tissue } \\
\text { expression }\end{array}$ & $\begin{array}{l}\text { OS, DFS, lymph node metastasis, } \\
\text { TNM stage }\end{array}$ & [96] \\
\hline $\begin{array}{l}\text { Panel (miR-675-5p, } \\
\text { miR-652-3p and } \\
\text { miR-338-3p) }\end{array}$ & iCCA & Overexpression & OS, DFS & [97] \\
\hline miR-29a & CCA & Overexpression & $\begin{array}{l}\text { OS, lymph node metastasis, } \\
\text { histological differentiation, } \\
\text { clinical staging }\end{array}$ & [98] \\
\hline $\operatorname{miR}-21$ & $\begin{array}{l}\text { Liver fluke-associated } \\
\text { iCCA }\end{array}$ & Overexpression & OS, lymph-node metastasis & [174] \\
\hline miR-92b & CCA & Overexpression & OS & [175] \\
\hline $\operatorname{miR}-34 a$ & eCCA & Decreased expression & $\begin{array}{l}\text { OS, lymph-node metastasis, } \\
\text { clinical stage }\end{array}$ & [176] \\
\hline miR-181a & CCA & Overexpression & OS & [177] \\
\hline miR-191 & iCCA & Overexpression & OS, DFS & [178] \\
\hline miR-203, miR-373 & CCA & Decreased expression & OS, DFS & {$[178,179]$} \\
\hline miR-221 & eCCA & Overexpression & DFS & [180] \\
\hline
\end{tabular}


Supplementary Materials: The following supporting information can be downloaded at https: / / www.mdpi.com/article/10.3390/cancers14041026/s1, Table S1: Overview of current and ongoing clinical trials for therapies targeting IDH1/2 in CCA, Table S2: Overview of current and ongoing clinical trials for therapies targeting KRAS in CCA, Table S3: Overview of current and ongoing clinical trials for therapies targeting FGFR in CCA, Table S4: Overview of current and ongoing clinical trials for therapies targeting EGFR and VEGF in CCA, Table S5: Overview of current and ongoing clinical trials for targeted therapies including multikinase inhibitors in CCA, Table S6: Overview of current and ongoing clinical trials for therapies targeting the MET, notch, and chromatin remodeling pathways in CCA, Table S7: Overview of current and ongoing clinical trials for immunotherapies in CCA. References [181-199] are cited in the supplementary materials.

Author Contributions: S.P. and G.L. wrote the manuscript; S.P., S.R. and G.L. acquired the data; S.P. and G.L. drafted and revised the manuscript; Further authors (D.U., I.L., C.E., D.P.M., U.P., F.K., N.R., C.B., I.M.S., S.S., F.T., W.S., M.S. and J.P.) have substantially contributed to the final version of the manuscript. All authors have read and agreed to the published version of the manuscript.

Funding: This research received no external funding.

Institutional Review Board Statement: Not applicable.

Informed Consent Statement: Not applicable.

Data Availability Statement: No new data were created or analyzed in this study. Data sharing is not applicable to this article.

Conflicts of Interest: The authors declare no conflict of interest.

\section{References}

1. Khan, S.A.; Tavolari, S.; Brandi, G. Cholangiocarcinoma: Epidemiology and risk factors. Liver Int. 2019, 39 (Suppl. S1), 19-31. [CrossRef] [PubMed]

2. Saeed, A.; Park, R.; Al-Jumayli, M.; Al-Rajabi, R.; Sun, W. Biologics, Immunotherapy, and Future Directions in the Treatment of Advanced Cholangiocarcinoma. Clin. Color. Cancer 2019, 18, 81-90. [CrossRef] [PubMed]

3. Kendall, T.; Verheij, J.; Gaudio, E.; Evert, M.; Guido, M.; Goeppert, B.; Carpino, G. Anatomical, histomorphological and molecular classification of cholangiocarcinoma. Liver Int. 2019, 39 (Suppl. S1), 7-18. [CrossRef]

4. Razumilava, N.; Gores, G.J. Cholangiocarcinoma. Lancet 2014, 383, 2168-2179. [CrossRef]

5. Özdirik, B.; Müller, T.; Wree, A.; Tacke, F.; Sigal, M. The Role of Microbiota in Primary Sclerosing Cholangitis and Related Biliary Malignancies. Int. J. Mol. Sci. 2021, 22, 6975. [CrossRef] [PubMed]

6. Lurje, G.; Bednarsch, J.; Czigany, Z.; Lurje, I.; Schlebusch, I.K.; Boecker, J.; Meister, F.A.; Tacke, F.; Roderburg, C.; Dulk, M.D.; et al. The prognostic role of lymphovascular invasion and lymph node metastasis in perihilar and intrahepatic cholangiocarcinoma. Eur. J. Surg. Oncol. 2019, 45, 1468-1478. [CrossRef] [PubMed]

7. Bednarsch, J.; Czigany, Z.; Lurje, I.; Tacke, F.; Strnad, P.; Ulmer, T.F.; Gaisa, N.T.; Bruners, P.; Neumann, U.P.; Lurje, G. Leftversus right-sided hepatectomy with hilar en-bloc resection in perihilar cholangiocarcinoma. HPB 2020, 22, 437-444. [CrossRef] [PubMed]

8. Li, J.; Moustafa, M.; Linecker, M.; Lurje, G.; Capobianco, I.; Baumgart, J.; Ratti, F.; Rauchfuss, F.; Balci, D.; Fernandes, E.; et al. ALPPS for Locally Advanced Intrahepatic Cholangiocarcinoma: Did Aggressive Surgery Lead to the Oncological Benefit? An International Multi-Center Study. Ann. Surg. Oncol. 2020, 27, 1372-1384. [CrossRef]

9. Haber, P.K.; Wabitsch, S.; Kästner, A.; Andreou, A.; Krenzien, F.; Schöning, W.; Pratschke, J.; Schmelzle, M. Laparoscopic Liver Resection for Intrahepatic Cholangiocarcinoma: A Single-Center Experience. J. Laparoendosc. Adv. Surg. Tech. 2020, 30, 1354-1359. [CrossRef]

10. Jonas, S.; Krenzien, F.; Atanasov, G.; Hau, H.-M.; Gawlitza, M.; Moche, M.; Wiltberger, G.; Pratschke, J.; Schmelzle, M. Hilar en bloc resection for hilar cholangiocarcinoma in patients with limited liver capacities-Preserving parts of liver segment 4 . Eur. Surg. 2018, 50, 22-29. [CrossRef]

11. Krenzien, F.; Nevermann, N.; Krombholz, A.; Benzing, C.; Haber, P.; Fehrenbach, U.; Lurje, G.; Pelzer, U.; Pratschke, J.; Schmelzle, M.; et al. Treatment of Intrahepatic Cholangiocarcinoma-A Multidisciplinary Approach. Cancers 2022, $14,362$. [CrossRef]

12. Lurje, G.; Bednarsch, J.; Roderburg, C.; Trautwein, C.; Neumann, U.P. Aktueller Therapiealgorithmus des intrahepatischen cholangiozellulären Karzinoms. Der Chir. 2018, 89, 858-864. [CrossRef]

13. Bednarsch, J.; Neumann, U.P.; Lurje, G. Reply to: Does lymphovascular invasion really associate with decreased overall survival for patients with resected cholangiocarcinoma? Eur. J. Surg. Oncol. 2019, 45, 1513-1514. [CrossRef]

14. Schmelzle, M.; Schöning, W.; Pratschke, J. Chirurgische Therapie maligner Gallengangserkrankungen. Der Chirurg 2019, 91, 3-10. [CrossRef] 
15. Valle, J.W.; Borbath, I.; Khan, S.A.; Huguet, F.; Gruenberger, T.; Arnold, D. Biliary cancer: ESMO Clinical Practice Guidelines for diagnosis, treatment and follow-up. Ann. Oncol. 2016, 27, v28-v37. [CrossRef]

16. Bednarsch, J.; Czigany, Z.; Lurje, I.; Amygdalos, I.; Strnad, P.; Halm, P.; Wiltberger, G.; Ulmer, T.F.; Schulze-Hagen, M.; Bruners, P.; et al. Insufficient future liver remnant and preoperative cholangitis predict perioperative outcome in perihilar cholangiocarcinoma. HPB 2020, 23, 99-108. [CrossRef]

17. Bednarsch, J.; Czigany, Z.; Lurje, I.; Strnad, P.; Bruners, P.; Ulmer, T.F.; den Dulk, M.; Lurje, G.; Neumann, U.P. The role of ALPPS in intrahepatic cholangiocarcinoma. Langenbeck's Arch. Surg. 2019, 404, 885-894. [CrossRef]

18. Czigany, Z.; Pratschke, J.; Froněk, J.; Guba, M.; Schöning, W.; Raptis, D.A.; Andrassy, J.; Kramer, M.; Strnad, P.; Tolba, R.H.; et al. Hypothermic Oxygenated Machine Perfusion Reduces Early Allograft Injury and Improves Post-transplant Outcomes in Extended Criteria Donation Liver Transplantation from Donation After Brain Death. Ann. Surg. 2021, 274, 705-712. [CrossRef]

19. Pavicevic, S.; Uluk, D.; Reichelt, S.; Fikatas, P.; Globke, B.; Raschzok, N.; Schmelzle, M.; Öllinger, R.; Schöning, W.; Eurich, D.; et al Hypothermic oxygenated machine perfusion for extended criteria donor allografts-Preliminary experience with extended organ preservation times in the setting of organ reallocation. Artif. Organs 2021, 46, 306-311. [CrossRef]

20. Lauterio, A.; De Carlis, R.; Centonze, L.; Buscemi, V.; Incarbone, N.; Vella, I.; De Carlis, L. Current Surgical Management of Peri-Hilar and Intra-Hepatic Cholangiocarcinoma. Cancers 2021, 13, 3657. [CrossRef]

21. Vibert, E.; Boleslawski, E. Transplantation Versus Resection for Hilar Cholangiocarcinoma. Ann. Surg. 2019, 269, e5-e6. [CrossRef]

22. Ballman, K.V. Biomarker: Predictive or Prognostic? J. Clin. Oncol. 2015, 33, 3968-3971. [CrossRef]

23. FDA-NIH Biomarker Working Group. BEST (Biomarkers, EndpointS, and Other Tools) Resource [Internet]; Food and Drug Administration (US): Silver Spring, MD, USA; National Institutes of Health (US): Bethesda, MD, USA, 2016

24. Czigany, Z.; Lurje, I.; Schmelzle, M.; Schöning, W.; Öllinger, R.; Raschzok, N.; Sauer, I.M.; Tacke, F.; Strnad, P.; Trautwein, C.; et al Ischemia-Reperfusion Injury in Marginal Liver Grafts and the Role of Hypothermic Machine Perfusion: Molecular Mechanisms and Clinical Implications. J. Clin. Med. 2020, 9, 846. [CrossRef]

25. Hayes, D.F.; Bast, R.; Desch, C.E.; Fritsche, H.; Kemeny, N.E.; Jessup, J.M.; Locker, G.Y.; Macdonald, J.S.; Mennel, R.G.; Norton, L.; et al. Tumor Marker Utility Grading System: A Framework to Evaluate Clinical Utility of Tumor Markers. J. Natl. Cancer Inst. 1996, 88, 1456-1466. [CrossRef]

26. Nakamura, H.; Arai, Y.; Totoki, Y.; Shirota, T.; ElZawahry, A.; Kato, M.; Hama, N.; Hosoda, F.; Urushidate, T.; Ohashi, S.; et al. Genomic spectra of biliary tract cancer. Nat. Genet. 2015, 47, 1003-1010. [CrossRef]

27. Lowery, M.; Ptashkin, R.N.; Jordan, E.J.; Berger, M.F.; Zehir, A.; Capanu, M.; Kemeny, N.E.; O’Reilly, E.M.; El-Dika, I.; Jarnagin, W.R.; et al. Comprehensive Molecular Profiling of Intrahepatic and Extrahepatic Cholangiocarcinomas: Potential Targets for Intervention. Clin. Cancer Res. 2018, 24, 4154-4161. [CrossRef]

28. Nault, J.; Villanueva, A. Biomarkers for Hepatobiliary Cancers. Hepatology 2020, 73, 115-127. [CrossRef]

29. Churi, C.R.; Shroff, R.; Wang, Y.; Rashid, A.; Kang, H.; Weatherly, J.; Zuo, M.; Zinner, R.; Hong, D.; Meric-Bernstam, F.; et al. Mutation Profiling in Cholangiocarcinoma: Prognostic and Therapeutic Implications. PLoS ONE 2014, 9, e115383. [CrossRef]

30. Banales, J.M.; Marin, J.J.G.; Lamarca, A.; Rodrigues, P.M.; Khan, S.A.; Roberts, L.R.; Cardinale, V.; Carpino, G.; Andersen, J.B.; Braconi, C.; et al. Cholangiocarcinoma 2020: The next horizon in mechanisms and management. Nat. Rev. Gastroenterol. Hepatol. 2020, 17, 557-588. [CrossRef]

31. Bolm, L.; Petrova, E.; Weitz, J.; Rückert, F.; Wittel, U.A.; Makowiec, F.; Lapshyn, H.; Bronsert, P.; Rau, B.M.; Khatkov, I.E.; et al. Prognostic relevance of preoperative bilirubin-adjusted serum carbohydrate antigen 19-9 in a multicenter subset analysis of 179 patients with distal cholangiocarcinoma. HPB 2019, 21, 1513-1519. [CrossRef] [PubMed]

32. Cai, W.-K.; Lin, J.-J.; He, G.-H.; Wang, H.; Lu, J.-H.; Yang, G.-S. Preoperative serum CA19-9 levels is an independent prognostic factor in patients with resected hilar cholangiocarcinoma. Int. J. Clin. Exp. Pathol. 2014, 7, 7890-7898. [PubMed]

33. Lee, B.S.; Lee, S.H.; Son, J.H.; Jang, D.K.; Chung, K.H.; Paik, W.H.; Ryu, J.K.; Kim, Y.-T. Prognostic value of CA 19-9 kinetics during gemcitabine-based chemotherapy in patients with advanced cholangiocarcinoma. J. Gastroenterol. Hepatol. 2016, 31, 493-500. [CrossRef] [PubMed]

34. Liang, B.; Zhong, L.; He, Q.; Wang, S.; Pan, Z.; Wang, T.; Zhao, Y. Diagnostic Accuracy of Serum CA19-9 in Patients with Cholangiocarcinoma: A Systematic Review and Meta-Analysis. Med. Sci. Monit. 2015, 21, 3555-3563. [CrossRef] [PubMed]

35. Loosen, S.H.; Roderburg, C.; Kauertz, K.L.; Koch, A.; Vucur, M.; Schneider, A.T.; Binnebösel, M.; Ulmer, T.F.; Lurje, G.; Schoening, W.; et al. CEA but not CA19-9 is an independent prognostic factor in patients undergoing resection of cholangiocarcinoma. Sci. Rep. 2017, 7, 16975. [CrossRef]

36. Fang, T.; Wang, H.; Wang, Y.; Lin, X.; Cui, Y.; Wang, Z. Clinical Significance of Preoperative Serum CEA, CA125, and CA19-9 Levels in Predicting the Resectability of Cholangiocarcinoma. Dis. Markers 2019, 2019, e6016931. [CrossRef]

37. Li, Y.; Li, D.-J.; Chen, J.; Liu, W.; Li, J.-W.; Jiang, P.; Zhao, X.; Guo, F.; Li, X.-W.; Wang, S.-G.; et al. Application of Joint Detection of AFP, CA19-9, CA125 and CEA in Identification and Diagnosis of Cholangiocarcinoma. Asian Pac. J. Cancer Prev. 2015, 16, 3451-3455. [CrossRef]

38. Qiu, Y.; He, J.; Chen, X.; Huang, P.; Hu, K.; Yan, H. The diagnostic value of five serum tumor markers for patients with cholangiocarcinoma. Clin. Chim. Acta 2018, 480, 186-192. [CrossRef]

39. Luo, X.; Yuan, L.; Wang, Y.; Ge, R.; Sun, Y.; Wei, G. Survival Outcomes and Prognostic Factors of Surgical Therapy for All Potentially Resectable Intrahepatic Cholangiocarcinoma: A Large Single-Center Cohort Study. J. Gastrointest. Surg. 2014, 18, 562-572. [CrossRef] 
40. Qiang, Z.-Y.; Zhang, W.-H.; Jin, S.; Dai, K.-F.; He, Y.-T.; Tao, L.-Y.; Yu, H.-B. Carcinoembryonic antigen, $\alpha$-fetoprotein, and Ki67 as biomarkers and prognostic factors in intrahepatic cholangiocarcinoma: A retrospective cohort study. Ann. Hepatol. 2020, 20, 100242. [CrossRef]

41. Moro, A.; Mehta, R.; Sahara, K.; Tsilimigras, D.I.; Paredes, A.Z.; Farooq, A.; Hyer, J.M.; Endo, I.; Shen, F.; Guglielmi, A.; et al. The Impact of Preoperative CA19-9 and CEA on Outcomes of Patients with Intrahepatic Cholangiocarcinoma. Ann. Surg. Oncol. 2020, 27, 2888-2901. [CrossRef]

42. He, C.; Zhang, Y.; Song, Y.; Wang, J.; Xing, K.; Lin, X.; Li, S. Preoperative CEA levels are supplementary to CA19-9 levels in predicting prognosis in patients with resectable intrahepatic cholangiocarcinoma. J. Cancer 2018, 9, 3117-3128. [CrossRef]

43. Huang, L.; Chen, W.; Liang, P.; Hu, W.; Zhang, K.; Shen, S.; Chen, J.; Zhang, Z.; Chen, B.; Han, Y.; et al. Serum CYFRA 21-1 in Biliary Tract Cancers: A Reliable Biomarker for Gallbladder Carcinoma and Intrahepatic Cholangiocarcinoma. Am. J. Dig. Dis. 2014, 60, 1273-1283. [CrossRef]

44. Itatsu, K.; Zen, Y.; Ohira, S.; Ishikawa, A.; Sato, Y.; Harada, K.; Ikeda, H.; Sasaki, M.; Nimura, Y.; Nakanuma, Y. Immunohistochemical analysis of the progression of flat and papillary preneoplastic lesions in intrahepatic cholangiocarcinogenesis in hepatolithiasis. Liver Int. 2007, 27, 1174-1184. [CrossRef]

45. Loosen, S.H.; Roderburg, C.; Kauertz, K.L.; Pombeiro, I.; Leyh, C.; Benz, F.; Vucur, M.; Longerich, T.; Koch, A.; Braunschweig, T.; et al. Elevated levels of circulating osteopontin are associated with a poor survival after resection of cholangiocarcinoma. J. Hepatol. 2017, 67, 749-757. [CrossRef]

46. Zhou, K.-Q.; Liu, W.-F.; Yang, L.-X.; Sun, Y.-F.; Hu, J.; Chen, F.-Y.; Zhou, C.; Zhang, X.-Y.; Peng, Y.-F.; Yu, L.; et al. Circulating osteopontin per tumor volume as a prognostic biomarker for resectable intrahepatic cholangiocarcinoma. Hepatobiliary Surg. Nutr. 2019, 8, 582-596. [CrossRef]

47. Asukai, K.; Kawamoto, K.; Eguchi, H.; Konno, M.; Nishida, N.; Koseki, J.; Noguchi, K.; Hasegawa, S.; Ogawa, H.; Yamada, D.; et al. Prognostic Impact of Peritumoral IL-17-Positive Cells and IL-17 Axis in Patients with Intrahepatic Cholangiocarcinoma. Ann. Surg. Oncol. 2015, 22, 1524-1531. [CrossRef]

48. Loosen, S.H.; Breuer, A.; Tacke, F.; Kather, J.N.; Gorgulho, J.; Alizai, P.H.; Bednarsch, J.; Roeth, A.A.; Lurje, G.; Schmitz, S.M.; et al. Circulating levels of soluble urokinase plasminogen activator receptor predict outcome after resection of biliary tract cancer. JHEP Rep. 2020, 2, 100080. [CrossRef]

49. Thummarati, P.; Wijitburaphat, S.; Prasopthum, A.; Menakongka, A.; Sripa, B.; Tohtong, R.; Suthiphongchai, T. High level of urokinase plasminogen activator contributes to cholangiocarcinoma invasion and metastasis. World J. Gastroenterol. 2012, 18, 244-250. [CrossRef]

50. Grunnet, M.; Christensen, I.; Lassen, U.; Jensen, L.; Lydolph, M.; Lund, I.; Thurison, T.; Høyer-Hansen, G.; Mau-Sørensen, M. Prognostic significance of circulating intact and cleaved forms of urokinase plasminogen activator receptor in inoperable chemotherapy treated cholangiocarcinoma patients. Clin. Biochem. 2014, 47, 599-604. [CrossRef]

51. Lang, S.A.; Bednarsch, J.; Joechle, K.; Amygdalos, I.; Czigany, Z.; Heij, L.; Ulmer, T.F.; Neumann, U.P. Prognostic biomarkers for cholangiocarcinoma (CCA): State of the art. Expert Rev. Gastroenterol. Hepatol. 2021, 15, 497-510. [CrossRef]

52. Jing, C.-Y.; Fu, Y.-P.; Shen, H.-J.; Zheng, S.-S.; Lin, J.-J.; Yi, Y.; Huang, J.-L.; Xu, X.; Zhang, J.; Zhou, J.; et al. Albumin to gamma-glutamyltransferase ratio as a prognostic indicator in intrahepatic cholangiocarcinoma after curative resection. Oncotarget 2016, 8, 13293-13303. [CrossRef]

53. Sun, C.; Zhu, J.; Wu, B.; Chen, J.; Zhu, Z.; Cai, P.; Guo, W.; Gu, Z.; Wang, J.; Huang, S. Diagnostic and prognostic value of microRNAs in cholangiocarcinoma: A systematic review and meta-analysis. Cancer Manag. Res. 2018, 10, 2125-2139. [CrossRef]

54. Zhou, J.; Liu, Z.; Yang, S.; Li, X. Identification of microRNAs as biomarkers for cholangiocarcinoma detection: A diagnostic meta-analysis. Clin. Res. Hepatol. Gastroenterol. 2017, 41, 156-162. [CrossRef]

55. Liang, Z.; Liu, X.; Zhang, Q.; Wang, C.; Zhao, Y. Diagnostic value of microRNAs as biomarkers for cholangiocarcinoma. Dig. Liver Dis. 2016, 48, 1227-1232. [CrossRef]

56. Loosen, S.H.; Lurje, G.; Wiltberger, G.; Vucur, M.; Koch, A.; Kather, J.N.; Paffenholz, P.; Tacke, F.; Ulmer, F.T.; Trautwein, C.; et al. Serum levels of miR-29, miR-122, miR-155 and miR-192 are elevated in patients with cholangiocarcinoma. PLoS ONE 2019, 14, e0210944. [CrossRef]

57. Macias, R.I.R.; Kornek, M.; Rodrigues, P.M.; Paiva, N.A.; Castro, R.E.; Urban, S.; Pereira, S.P.; Cadamuro, M.; Rupp, C.; Loosen, S.H.; et al. Diagnostic and prognostic biomarkers in cholangiocarcinoma. Liver Int. 2019, 39, 108-122. [CrossRef] [PubMed]

58. Salem, P.E.S.; Ghazala, R.A.; El Gendi, A.M.; Emara, D.M.; Ahmed, N.M. The association between circulating MicroRNA-150 level and cholangiocarcinoma. J. Clin. Lab. Anal. 2020, 34, e23397. [CrossRef]

59. Andersen, R.F.; Jakobsen, A. Screening for circulating RAS/RAF mutations by multiplex digital PCR. Clin. Chim. Acta 2016, 458, 138-143. [CrossRef]

60. Lurje, G.; Nagashima, F.; Zhang, W.; Yang, D.; Chang, H.M.; Gordon, M.A.; El-Khoueiry, A.; Husain, H.; Wilson, P.M.; Ladner, R.D.; et al. Polymorphisms in cyclooxygenase-2 and epidermal growth factor receptor are associated with progressionfree survival independent of K-ras in metastatic colorectal cancer patients treated with single-agent cetuximab. Clin. Cancer Res. 2008, 14, 7884-7895. [CrossRef] 
61. Lurje, G.; Zhang, W.; Schultheis, A.M.; Yang, D.; Groshen, S.; Hendifar, A.E.; Husain, H.; Gordon, M.A.; Nagashima, F.; Chang, H.M.; et al. Polymorphisms in VEGF and IL-8 predict tumor recurrence in stage III colon cancer. Ann. Oncol. 2008, 19, 1734-1741. [CrossRef]

62. Lurje, G.; Husain, H.; Power, D.; Yang, D.; Groshen, S.; Pohl, A.; Zhang, W.; Ning, Y.; Manegold, P.; El-Khoueiry, A.; et al. Genetic variations in angiogenesis pathway genes associated with clinical outcome in localized gastric adenocarcinoma. Ann. Oncol. 2010, 21, 78-86. [CrossRef] [PubMed]

63. Lurje, G.; Leers, J.M.; Pohl, A.; Oezcelik, A.; Zhang, W.; Ayazi, S.; Winder, T.; Ning, Y.; Yang, D.; Klipfel, N.E.; et al. Genetic Variations in Angiogenesis Pathway Genes Predict Tumor Recurrence in Localized Adenocarcinoma of the Esophagus. Ann. Surg. 2010, 251, 857-864. [CrossRef] [PubMed]

64. Schneider, C.V.; Hamesch, K.; Gross, A.; Mandorfer, M.; Moeller, L.S.; Pereira, V.; Pons, M.; Kuca, P.; Reichert, M.C.; Benini, F.; et al. Liver Phenotypes of European Adults Heterozygous or Homozygous for Pi*Z Variant of AAT (Pi*MZ vs. Pi*ZZ genotype) and Noncarriers. Gastroenterology 2020, 159, 534-548. [CrossRef] [PubMed]

65. Lurje, I.; Czigany, Z.; Bednarsch, J.; Gaisa, N.T.; Dahl, E.; Knüchel, R.; Miller, H.; Ulmer, T.F.; Strnad, P.; Trautwein, C.; et al. Genetic variant of CXCR1 (rs2234671) associates with clinical outcome in perihilar cholangiocarcinoma. Liver Cancer 2022, in press. [CrossRef]

66. Fingas, C.D.; Katsounas, A.; Kahraman, A.; Siffert, W.; Jochum, C.; Gerken, G.; Nückel, H.; Canbay, A. Prognostic Assessment of Three Single-Nucleotide Polymorphisms (GNB3825C>T,BCL2-938C>A,MCL1-386C>G) in Extrahepatic Cholangiocarcinoma. Cancer Investig. 2009, 28, 472-478. [CrossRef]

67. Braconi, C.; Roessler, S.; Kruk, B.; Lammert, F.; Krawczyk, M.; Andersen, J.B. Molecular perturbations in cholangiocarcinoma: Is it time for precision medicine? Liver Int. 2019, 39 (Suppl. S1), 32-42. [CrossRef]

68. Rhodes, K.; Zhang, W.; Yang, D.; Press, O.; Gordon, M.; Vallbohmer, D.; Schultheis, A.; Lurje, G.; Ladner, R.; Fazzone, W.; et al ABCB1, SLCO1B1 and UGT1A1 gene polymorphisms are associated with toxicity in metastatic colorectal cancer patients treated with first-line irinotecan. Drug Metab. Lett. 2007, 1, 23-30. [CrossRef]

69. Lurje, G.; Schiesser, M.; Hoffmann, A.C.; Schneider, P.M. Circulating Tumor Cells in Gastrointestinal Malignancies: Current Techniques and Clinical Implications. J. Oncol. 2009, 2010, e392652. [CrossRef]

70. Andersen, J.B.; Spee, B.; Blechacz, B.R.; Avital, I.; Komuta, M.; Barbour, A.; Conner, E.A.; Gillen, M.C.; Roskams, T.; Roberts, L.; et al. Genomic and Genetic Characterization of Cholangiocarcinoma Identifies Therapeutic Targets for Tyrosine Kinase Inhibitors. Gastroenterology 2012, 142, 1021-1031.e15. [CrossRef]

71. Namjan, A.; Techasen, A.; Loilome, W.; Sa-Ngaimwibool, P.; Jusakul, A. ARID1A alterations and their clinical significance in cholangiocarcinoma. PeerJ 2020, 8, e10464. [CrossRef]

72. Sasaki, M.; Nitta, T.; Sato, Y.; Nakanuma, Y. Loss of ARID1A Expression Presents a Novel Pathway of Carcinogenesis in Biliary Carcinomas. Am. J. Clin. Pathol. 2016, 145, 815-825. [CrossRef]

73. Bi, C.; Liu, M.; Rong, W.; Wu, F.; Zhang, Y.; Lin, S.; Liu, Y.; Wu, J.; Wang, L. High Beclin-1 and ARID1A expression corelates with poor survival and high recurrence in intrahepatic cholangiocarcinoma: A histopathological retrospective study. BMC Cancer 2019, 19, 213. [CrossRef]

74. Ruys, A.T.; Koerkamp, B.G.; Wiggers, J.K.; Klümpen, H.-J.; Kate, F.J.T.; Van Gulik, T.M. Prognostic Biomarkers in Patients with Resected Cholangiocarcinoma: A Systematic Review and Meta-analysis. Ann. Surg. Oncol. 2013, 21, 487-500. [CrossRef]

75. Jones, R.P.; Bird, N.T.; Smith, R.A.; Palmer, D.H.; Fenwick, S.W.; Poston, G.J.; Malik, H.Z. Prognostic molecular markers in resected extrahepatic biliary tract cancers: A systematic review and meta-analysis of immunohistochemically detected biomarkers Biomarkers Med. 2015, 9, 763-775. [CrossRef]

76. Ghidini, M.; Cascione, L.; Carotenuto, P.; Lampis, A.; Trevisani, F.; Previdi, M.C.; Hahne, J.C.; Said-Huntingford, I.; Raj, M.; Zerbi, A.; et al. Characterisation of the immune-related transcriptome in resected biliary tract cancers. Eur. J. Cancer 2017, 86, 158-165. [CrossRef]

77. Huang, D.-W.; Huang, M.; Lin, X.-S.; Huang, Q. CD155 expression and its correlation with clinicopathologic characteristics, angiogenesis, and prognosis in human cholangiocarcinoma. OncoTargets Ther. 2017, ume 10, 3817-3825. [CrossRef]

78. Thanee, M.; Loilome, W.; Techasen, A.; Sugihara, E.; Okazaki, S.; Abe, S.; Ueda, S.; Masuko, T.; Namwat, N.; Khuntikeo, N.; et al. CD44 variant-dependent redox status regulation in liver fluke-associated cholangiocarcinoma: A target for cholangiocarcinoma treatment. Cancer Sci. 2016, 107, 991-1000. [CrossRef]

79. Saengboonmee, C.; Sawanyawisuth, K.; Chamgramol, Y.; Wongkham, S. Prognostic biomarkers for cholangiocarcinoma and their clinical implications. Expert Rev. Anticancer Ther. 2018, 18, 579-592. [CrossRef]

80. Wang, Y.; Wan, M.; Zhou, Q.; Wang, H.; Wang, Z.; Zhong, X.; Zhang, L.; Tai, S.; Cui, Y. The Prognostic Role of SOCS3 and A20 in Human Cholangiocarcinoma. PLoS ONE 2015, 10, e0141165. [CrossRef]

81. Talabnin, C.; Janthavon, P.; Thongsom, S.; Suginta, W.; Talabnin, K.; Wongkham, S. Ring finger protein 43 expression is associated with genetic alteration status and poor prognosis among patients with intrahepatic cholangiocarcinoma. Hum. Pathol. 2016, 52, 47-54. [CrossRef]

82. Zhang, H.; Li, Z.; Chu, B.; Zhang, F.; Zhang, Y.; Ke, F.; Chen, Y.; Xu, Y.; Liu, S.; Zhao, S.; et al. Upregulated LASP-1 correlates with a malignant phenotype and its potential therapeutic role in human cholangiocarcinoma. Tumor Biol. 2016, 37, 8305-8315. [CrossRef] [PubMed] 
83. Zhao, X.; Guo, F.; Li, Z.; Jiang, P.; Deng, X.; Tian, F.; Li, X.; Wang, S. Aberrant expression of B7-H4 correlates with poor prognosis and suppresses tumor-infiltration of CD8+ T lymphocytes in human cholangiocarcinoma. Oncol. Rep. 2016, 36, 419-427. [CrossRef] [PubMed]

84. Guo, S.; Liu, H.-D.; Liu, Y.-F.; Liu, L.; Sun, Q.; Cui, X.-J. Hepatoma-derived growth factor: A novel prognostic biomarker in intrahepatic cholangiocarcinoma. Tumor Biol. 2014, 36, 353-364. [CrossRef] [PubMed]

85. Zhao, W.; Zhang, B.; Guo, X.; Zhang, X.; Hu, J.; Hu, X.; Lu, Y. Expression of Ki-67, Bax and p73 in patients with hilar cholangiocarcinoma. Cancer Biomark. 2014, 14, 197-202. [CrossRef]

86. Wang, W.; Zhang, J.; Zhan, X.; Lin, T.; Yang, M.; Hu, J.; Han, B.; Hu, S. SOX4 is associated with poor prognosis in cholangiocarcinoma. Biochem. Biophys. Res. Commun. 2014, 452, 614-621. [CrossRef]

87. Yoh, T.; Hatano, E.; Kasai, Y.; Fuji, H.; Nishi, K.; Toriguchi, K.; Sueoka, H.; Ohno, M.; Seo, S.; Iwaisako, K.; et al. Serum Nardilysin, a Surrogate Marker for Epithelial-Mesenchymal Transition, Predicts Prognosis of Intrahepatic Cholangiocarcinoma after Surgical Resection. Clin. Cancer Res. 2018, 25, 619-628. [CrossRef]

88. Boonla, C.; Sripa, B.; Thuwajit, P.; Cha-On, U.; Puapairoj, A.; Miwa, M.; Wongkham, S. MUC1 and MUC5AC mucin expression in liver fluke-associated intrahepatic cholangiocarcinoma. World J. Gastroenterol. 2005, 11, 4939-4946. [CrossRef]

89. Abe, T.; Amano, H.; Shimamoto, F.; Hattori, M.; Kuroda, S.; Kobayashi, T.; Tashiro, H.; Ohdan, H. Prognostic evaluation of mucin-5AC expression in intrahepatic cholangiocarcinoma, mass-forming type, following hepatectomy. Eur. J. Surg. Oncol. 2015, 41, 1515-1521. [CrossRef]

90. Sulpice, L.; Rayar, M.; Turlin, B.; Boucher, E.; Bellaud, P.; Desille, M.; Meunier, B.; Clément, B.; Boudjema, K.; Coulouarn, C. Epithelial cell adhesion molecule is a prognosis marker for intrahepatic cholangiocarcinoma. J. Surg. Res. 2014, 192, 117-123. [CrossRef]

91. Bergeat, D.; Fautrel, A.; Turlin, B.; Merdrignac, A.; Rayar, M.; Boudjema, K.; Coulouarn, C.; Sulpice, L. Impact of stroma LOXL2 overexpression on the prognosis of intrahepatic cholangiocarcinoma. J. Surg. Res. 2016, 203, 441-450. [CrossRef]

92. Sun, Q.; Zhao, C.; Xia, L.; He, Z.; Lu, Z.; Liu, C.; Jia, M.; Wang, J.; Niu, J. High expression of matrix metalloproteinase-9 indicates poor prognosis in human hilar cholangiocarcinoma. Int. J. Clin. Exp. Pathol. 2014, 7, 6157-6164.

93. Tongtawee, T.; Kaewpitoon, S.J.; Loyd, R.; Chanvitan, S.; Leelawat, K.; Praditpol, N.; Jujinda, S.; Kaewpitoon, N. High Expression of Matrix Metalloproteinase-11 indicates Poor Prognosis in Human Cholangiocarcinoma. Asian Pac. J. Cancer Prev. 2015, 16, 3697-3701. [CrossRef]

94. Sun, Q.; Li, F.; Sun, F.; Niu, J. Interleukin-8 is a prognostic indicator in human hilar cholangiocarcinoma. Int. J. Clin. Exp. Pathol. 2015, 8, 8376-8384.

95. Xu, Y.; Wang, Z.; Jiang, X.; Cui, Y. Overexpression of long noncoding RNA H19 indicates a poor prognosis for cholangiocarcinoma and promotes cell migration and invasion by affecting epithelial-mesenchymal transition. Biomed. Pharmacother. 2017, 92, 17-23. [CrossRef]

96. Xu, Y.; Jiang, X.; Cui, Y. Upregulated long noncoding RNA PANDAR predicts an unfavorable prognosis and promotes tumorigenesis in cholangiocarcinoma. OncoTargets Ther. 2017, 10, 2873-2883. [CrossRef]

97. Zhang, M.-Y.; Li, S.-H.; Huang, G.-L.; Lin, G.-H.; Shuang, Z.-Y.; Lao, X.-M.; Xu, L.; Lin, X.-J.; Wang, H.-Y.; Li, S.-P. Identification of a novel microRNA signature associated with intrahepatic cholangiocarcinoma (ICC) patient prognosis. BMC Cancer 2015, 15, 64. [CrossRef]

98. Deng, Y.; Chen, Y. Increased Expression of miR-29a and Its Prognostic Significance in Patients with Cholangiocarcinoma. Oncol. Res. Treat. 2017, 40, 128-132. [CrossRef]

99. Ikeno, Y.; Seo, S.; Iwaisako, K.; Yoh, T.; Nakamoto, Y.; Fuji, H.; Taura, K.; Okajima, H.; Kaido, T.; Sakaguchi, S.; et al. Preoperative metabolic tumor volume of intrahepatic cholangiocarcinoma measured by 18F-FDG-PET is associated with the KRAS mutation status and prognosis. J. Transl. Med. 2018, 16, 95. [CrossRef]

100. Primrose, J.N.; Fox, R.P.; Palmer, D.H.; Malik, H.Z.; Prasad, R.; Mirza, D.; Anthony, A.; Corrie, P.; Falk, S.; Finch-Jones, M.; et al Capecitabine compared with observation in resected biliary tract cancer (BILCAP): A randomised, controlled, multicentre, phase 3 study. Lancet Oncol. 2019, 20, 663-673. [CrossRef]

101. Stein, A.; Arnold, D.; Bridgewater, J.; Goldstein, D.; Jensen, L.H.; Klümpen, H.-J.; Lohse, A.W.; Nashan, B.; Primrose, J.; Schrum, S.; et al. Adjuvant chemotherapy with gemcitabine and cisplatin compared to observation after curative intent resection of cholangiocarcinoma and muscle invasive gallbladder carcinoma (ACTICCA-1 trial) —A randomized, multidisciplinary, multinational phase III trial. BMC Cancer 2015, 15, 564. [CrossRef]

102. Valle, J.W.; Furuse, J.; Jitlal, M.; Beare, S.; Mizuno, N.; Wasan, H.; Bridgewater, J.; Okusaka, T. Cisplatin and gemcitabine for advanced biliary tract cancer: A meta-analysis of two randomised trials. Ann. Oncol. 2013, 25, 391-398. [CrossRef]

103. Voss, M.H.; Hierro, C.; Heist, R.S.; Cleary, J.M.; Meric-Bernstam, F.; Tabernero, J.; Janku, F.; Gandhi, L.; Iafrate, A.J.; Borger, D.R.; et al. A Phase I, Open-Label, Multicenter, Dose-escalation Study of the Oral Selective FGFR Inhibitor Debio 1347 in Patients with Advanced Solid Tumors Harboring FGFR Gene Alterations. Clin. Cancer Res. 2019, 25, 2699-2707. [CrossRef]

104. Goyal, L.; Saha, S.K.; Liu, L.Y.; Siravegna, G.; Leshchiner, I.; Ahronian, L.G.; Lennerz, J.K.; Vu, P.; Deshpande, V.; Kambadakone, A.; et al. Polyclonal Secondary FGFR2 Mutations Drive Acquired Resistance to FGFR Inhibition in Patients with FGFR2 Fusion-Positive Cholangiocarcinoma. Cancer Discov. 2016, 7, 252-263. [CrossRef]

105. Mertens, J.C.; Rizvi, S.; Gores, G.J. Targeting cholangiocarcinoma. Biochim. Biophys. Acta Mol. Basis Dis. 2017, 1864, 1454-1460. [CrossRef] 
106. Borad, M.J.; Gores, G.J.; Roberts, L. Fibroblast growth factor receptor 2 fusions as a target for treating cholangiocarcinoma. Curr. Opin. Gastroenterol. 2015, 31, 264-268. [CrossRef]

107. Saka, H.; Kitagawa, C.; Kogure, Y.; Takahashi, Y.; Fujikawa, K.; Sagawa, T.; Iwasa, S.; Takahashi, N.; Fukao, T.; Tchinou, C.; et al. Safety, tolerability and pharmacokinetics of the fibroblast growth factor receptor inhibitor AZD4547 in Japanese patients with advanced solid tumours: A Phase I study. Investig. New Drugs 2017, 35, 451-462. [CrossRef]

108. Bahleda, R.; Italiano, A.; Hierro, C.; Mita, A.; Cervantes, A.; Chan, N.; Awad, M.; Calvo, E.; Moreno, V.; Govindan, R.; et al. Multicenter Phase I Study of Erdafitinib (JNJ-42756493), Oral Pan-Fibroblast Growth Factor Receptor Inhibitor, in Patients with Advanced or Refractory Solid Tumors. Clin. Cancer Res. 2019, 25, 4888-4897. [CrossRef]

109. Kurzrock, R.; Ball, D.W.; Zahurak, M.L.; Nelkin, B.D.; Subbiah, V.; Ahmed, S.; O'Connor, A.; Karunsena, E.; Parkinson, R.M.; Bishop, J.A.; et al. A Phase I Trial of the VEGF Receptor Tyrosine Kinase Inhibitor Pazopanib in Combination with the MEK Inhibitor Trametinib in Advanced Solid Tumors and Differentiated Thyroid Cancers. Clin. Cancer Res. 2019, 25, 5475-5484. [CrossRef] [PubMed]

110. Javle, M.; Bekaii-Saab, T.; Jain, A.; Wang, Y.; Kelley, R.K.; Wang, K.; Kang, H.C.; Catenacci, D.; Ali, S.; Krishnan, S.; et al. Biliary cancer: Utility of next-generation sequencing for clinical management. Cancer 2016, 122, 3838-3847. [CrossRef] [PubMed]

111. Goyal, L.; Meric-Bernstam, F.; Hollebecque, A.; Valle, J.W.; Morizane, C.; Karasic, T.B.; Abrams, T.A.; Furuse, J.; He, Y.; Soni, N.; et al. FOENIX-CCA2: A phase II, open-label, multicenter study of futibatinib in patients (pts) with intrahepatic cholangiocarcinoma (iCCA) harboring FGFR2 gene fusions or other rearrangements. J. Clin. Oncol. 2020, 38, 108. [CrossRef]

112. Mazzaferro, V.; El-Rayes, B.F.; Busset, M.D.D.; Cotsoglou, C.; Harris, W.P.; Damjanov, N.; Masi, G.; Rimassa, L.; Personeni, N.; Braiteh, F.; et al. Derazantinib (ARQ 087) in advanced or inoperable FGFR2 gene fusion-positive intrahepatic cholangiocarcinoma. Br. J. Cancer 2018, 120, 165-171. [CrossRef]

113. Javle, M.; Lowery, M.; Shroff, R.T.; Weiss, K.H.; Springfeld, C.; Borad, M.J.; Ramanathan, R.K.; Goyal, L.; Sadeghi, S.; Macarulla, T.; et al. Phase II Study of BGJ398 in Patients with FGFR-Altered Advanced Cholangiocarcinoma. J. Clin. Oncol. 2018, 36, 276-282. [CrossRef]

114. Javle, M.M.; Roychowdhury, S.; Kelley, R.K.; Sadeghi, S.; Macarulla, T.; Waldschmidt, D.T.; Goyal, L.; Borbath, I.; El-Khoueiry, A.B.; Yong, W.-P.; et al. Final results from a phase II study of infigratinib (BGJ398), an FGFR-selective tyrosine kinase inhibitor, in patients with previously treated advanced cholangiocarcinoma harboring an FGFR2 gene fusion or rearrangement. J. Clin. Oncol. 2021, 39, 265. [CrossRef]

115. Javle, M.; Kelley, R.; Roychowdhury, S.; Weiss, K.; Abou-Alfa, G.; Macarulla, T.; Sadeghi, S.; Waldschmidt, D.; Zhu, A.; Goyal, L.; et al. Updated results from a phase II study of infigratinib (BGJ398), a selective pan-FGFR kinase inhibitor, in patients with previously treated advanced cholangiocarcinoma containing FGFR2 fusions. Ann. Oncol. 2018, 29, viii720. [CrossRef]

116. Makawita, S.; Abou-Alfa, G.K.; Roychowdhury, S.; Sadeghi, S.; Borbath, I.; Goyal, L.; Cohn, A.; Lamarca, A.; Oh, D.-Y.; Macarulla, T.; et al. Infigratinib in patients with advanced cholangiocarcinoma with FGFR2 gene fusions/translocations: The PROOF 301 trial. Futur. Oncol. 2020, 16, 2375-2384. [CrossRef]

117. Borad, M.J.; Bridgewater, J.A.; Morizane, C.; Shroff, R.T.; Oh, D.-Y.; Moehler, M.H.; Furuse, J.; Benhadji, K.A.; He, H.; Valle, J.W. A phase III study of futibatinib (TAS-120) versus gemcitabine-cisplatin (gem-cis) chemotherapy as first-line (1L) treatment for patients (pts) with advanced (adv) cholangiocarcinoma (CCA) harboring fibroblast growth factor receptor 2 (FGFR2) gene rearrangements (FOENIX-CCA3). J. Clin. Oncol. 2020, 38, TPS600. [CrossRef]

118. Bekaii-Saab, T.S.; Valle, J.W.; Van Cutsem, E.; Rimassa, L.; Furuse, J.; Ioka, T.; Melisi, D.; Macarulla, T.; Bridgewater, J.; Wasan, H.; et al. FIGHT-302: First-line pemigatinib vs gemcitabine plus cisplatin for advanced cholangiocarcinoma with FGFR2 rearrangements. Futur. Oncol. 2020, 16, 2385-2399. [CrossRef]

119. Terada, T.; Nakanuma, Y.; Sirica, A.E. Immunohistochemical demonstration of MET overexpression in human intrahepatic cholangiocarcinoma and in hepatolithiasis. Hum. Pathol. 1998, 29, 175-180. [CrossRef]

120. Pant, S.; Saleh, M.; Bendell, J.; Infante, J.; Jones, S.; Kurkjian, C.; Moore, K.; Kazakin, J.; Abbadessa, G.; Wang, Y.; et al. A phase I dose escalation study of oral c-MET inhibitor tivantinib (ARQ 197) in combination with gemcitabine in patients with solid tumors. Ann. Oncol. 2014, 25, 1416-1421. [CrossRef]

121. Goyal, L.; Zheng, H.; Yurgelun, M.B.; Abrams, T.A.; Allen, J.N.; Cleary, J.M.; Knowles, M.; Regan, E.; Reardon, A.; Khachatryan, A.; et al. A phase 2 and biomarker study of cabozantinib in patients with advanced cholangiocarcinoma. Cancer 2017, 123, 1979-1988. [CrossRef]

122. Simile, M.M.; Bagella, P.; Vidili, G.; Spanu, A.; Manetti, R.; Seddaiu, M.A.; Babudieri, S.; Madeddu, G.; Serra, P.A.; Altana, M.; et al. Targeted Therapies in Cholangiocarcinoma: Emerging Evidence from Clinical Trials. Medicina 2019, 55, 42. [CrossRef]

123. Sirica, A.-E. Role of ErbB family receptor tyrosine kinases in intrahepatic cholangiocarcinoma. World J. Gastroenterol. 2008, 14, 7033-7058. [CrossRef]

124. Yoshikawa, D.; Ojima, H.; Iwasaki, M.; Hiraoka, N.; Kosuge, T.; Kasai, S.; Hirohashi, S.; Shibata, T. Clinicopathological and prognostic significance of EGFR, VEGF, and HER2 expression in cholangiocarcinoma. Br. J. Cancer 2007, 98, 418-425. [CrossRef]

125. Lurje, G.; Lenz, H.-J. EGFR Signaling and Drug Discovery. Oncology 2009, 77, 400-410. [CrossRef]

126. Kotschy, A.; Szlavik, Z.; Murray, J.; Davidson, J.; Maragno, A.L.; Le Toumelin-Braizat, G.; Chanrion, M.; Kelly, G.L.; Gong, J.-N.; Moujalled, D.M.; et al. The MCL1 inhibitor S63845 is tolerable and effective in diverse cancer models. Nature 2016, 538, 477-482. [CrossRef] 
127. Lubner, S.J.; Mahoney, M.R.; Kolesar, J.L.; LoConte, N.K.; Kim, G.P.; Pitot, H.C.; Philip, P.A.; Picus, J.; Yong, W.-P.; Horvath, L.; et al. Report of a Multicenter Phase II Trial Testing a Combination of Biweekly Bevacizumab and Daily Erlotinib in Patients with Unresectable Biliary Cancer: A Phase II Consortium Study. J. Clin. Oncol. 2010, 28, 3491-3497. [CrossRef]

128. Philip, P.A.; Mahoney, M.R.; Allmer, C.; Thomas, J.; Pitot, H.C.; Kim, G.; Donehower, R.C.; Fitch, T.; Picus, J.; Erlichman, C. Phase II Study of Erlotinib in Patients with Advanced Biliary Cancer. J. Clin. Oncol. 2006, 24, 3069-3074. [CrossRef]

129. Gruenberger, B.; Schueller, J.; Heubrandtner, U.; Wrba, F.; Tamandl, D.; Kaczirek, K.; Roka, R.; Freimann-Pircher, S.; Gruenberger, T. Cetuximab, gemcitabine, and oxaliplatin in patients with unresectable advanced or metastatic biliary tract cancer: A phase 2 study. Lancet Oncol. 2010, 11, 1142-1148. [CrossRef]

130. Ramanathan, R.K.; Belani, C.; Singh, D.A.; Tanaka, M.; Lenz, H.-J.; Yen, Y.; Kindler, H.L.; Iqbal, S.; Longmate, J.; Mack, P.C.; et al. A phase II study of lapatinib in patients with advanced biliary tree and hepatocellular cancer. Cancer Chemother. Pharmacol. 2009, 64, 777-783. [CrossRef]

131. Peck, J.; Wei, L.; Zalupski, M.; O’Neil, B.; Calero, M.V.; Bekaii-Saab, T. HER2/neu May Not Be an Interesting Target in Biliary Cancers: Results of an Early Phase II Study with Lapatinib. Oncology 2012, 82, 175-179. [CrossRef] [PubMed]

132. Jensen, L.H.; Lindebjerg, J.; Ploen, J.; Hansen, T.; Jakobsen, A. Phase II marker-driven trial of panitumumab and chemotherapy in KRAS wild-type biliary tract cancer. Ann. Oncol. 2012, 23, 2341-2346. [CrossRef] [PubMed]

133. Leone, F.; Marino, D.; Cereda, S.; Filippi, R.; Belli, C.; Spadi, R.; Nasti, G.; Montano, M.; Amatu, A.; Aprile, G.; et al. Panitumumab in combination with gemcitabine and oxaliplatin does not prolong survival in wild-typeKRASadvanced biliary tract cancer: A randomized phase 2 trial (Vecti-BIL study). Cancer 2015, 122, 574-581. [CrossRef] [PubMed]

134. Ole Larsen, F.; Taksony Solyom Hoegdall, D.; Hoegdall, E.; Nielsen, D. Gemcitabine, capecitabine and oxaliplatin with or without cetuximab in advanced biliary tract carcinoma. Acta Oncol. 2015, 55, 382-385. [CrossRef] [PubMed]

135. Lee, J.; Park, S.H.; Chang, H.M.; Kim, J.S.; Choi, H.J.; Lee, M.A.; Jang, J.S.; Jeung, H.C.; Kang, J.H.; Lee, H.W.; et al. Gemcitabine and oxaliplatin with or without erlotinib in advanced biliary-tract cancer: A multicentre, open-label, randomised, phase 3 study. Lancet Oncol. 2012, 13, 181-188. [CrossRef]

136. Galdy, S.; Lamarca, A.; Mcnamara, M.; Hubner, R.A.; Cella, C.A.; Fazio, N.; Valle, J.W. HER2/HER3 pathway in biliary tract malignancies; systematic review and meta-analysis: A potential therapeutic target? Cancer Metastasis Rev. 2016, 36, 141-157. [CrossRef]

137. Javle, M.; Borad, M.J.; Azad, N.S.; Kurzrock, R.; Abou-Alfa, G.K.; George, B.; Hainsworth, J.; Meric-Bernstam, F.; Swanton, C.; Sweeney, C.J.; et al. Pertuzumab and trastuzumab for HER2-positive, metastatic biliary tract cancer (MyPathway): A multicentre, open-label, phase 2a, multiple basket study. Lancet Oncol. 2021, 22, 1290-1300. [CrossRef]

138. Javle, M.; Churi, C.; Kang, H.; Shroff, R.T.; Janku, F.; Surapaneni, R.; Zuo, M.; Barrera, C.; Alshamsi, H.O.; Krishnan, S.; et al. HER2/neu-directed therapy for biliary tract cancer. J. Hematol. Oncol. 2015, 8, 58. [CrossRef]

139. Larsen, F.O.; Markussen, A.; Diness, L.V.; Nielsen, D. Efficacy and Safety of Capecitabine, Irinotecan, Gemcitabine, and Bevacizumab as Second-Line Treatment in Advanced Biliary Tract Cancer: A Phase II Study. Oncology 2017, 94, 19-24. [CrossRef]

140. Zhu, A.X.; Meyerhardt, J.A.; Blaszkowsky, L.S.; Kambadakone, A.R.; Muzikansky, A.; Zheng, H.; Clark, J.W.; Abrams, T.A.; A Chan, J.; Enzinger, P.C.; et al. Efficacy and safety of gemcitabine, oxaliplatin, and bevacizumab in advanced biliary-tract cancers and correlation of changes in 18-fluorodeoxyglucose PET with clinical outcome: A phase 2 study. Lancet Oncol. 2009, 11, 48-54. [CrossRef]

141. Iyer, R.V.; Pokuri, V.K.; Groman, A.; Ma, W.W.; Malhotra, U.; Iancu, D.M.; Grande, C.; Saab, T.B. A Multicenter Phase II Study of Gemcitabine, Capecitabine, and Bevacizumab for Locally Advanced or Metastatic Biliary Tract Cancer. Am. J. Clin. Oncol. 2018, 41, 649-655. [CrossRef]

142. Bengala, C.; Bertolini, F.; Malavasi, N.; Boni, C.; Aitini, E.; Dealis, C.; Zironi, S.; Depenni, R.; Fontana, A.; Del Giovane, C.; et al. Sorafenib in patients with advanced biliary tract carcinoma: A phase II trial. Br. J. Cancer 2009, 102, 68-72. [CrossRef]

143. El-Khoueiry, A.B.; Rankin, C.J.; Ben-Josef, E.; Lenz, H.-J.; Gold, P.J.; Hamilton, R.D.; Govindarajan, R.; Eng, C.; Blanke, C.D. SWOG 0514: A phase II study of sorafenib in patients with unresectable or metastatic gallbladder carcinoma and cholangiocarcinoma. Investig. New Drugs 2011, 30, 1646-1651. [CrossRef]

144. Lee, J.K.; Capanu, M.; O’Reilly, E.M.; Ma, J.; Chou, J.F.; Shia, J.; Katz, S.; Gansukh, B.; Reidylagunes, D.; Segal, N.H.; et al. A phase II study of gemcitabine and cisplatin plus sorafenib in patients with advanced biliary adenocarcinomas. Br. J. Cancer 2013, 109, 915-919. [CrossRef]

145. Moehler, M.; Maderer, A.; Schimanski, C.; Kanzler, S.; Denzer, U.; Kolligs, F.; Ebert, M.; Distelrath, A.; Geissler, M.; Trojan, J.; et al. Gemcitabine plus sorafenib versus gemcitabine alone in advanced biliary tract cancer: A double-blind placebo-controlled multicentre phase II AIO study with biomarker and serum programme. Eur. J. Cancer 2014, 50, 3125-3135. [CrossRef]

146. Sun, W.; Patel, A.; Normolle, D.; Patel, K.; Ohr, J.; Lee, J.J.; Bahary, N.; Chu, E.; Streeter, N.; Drummond, S. A phase 2 trial of regorafenib as a single agent in patients with chemotherapy-refractory, advanced, and metastatic biliary tract adenocarcinoma. Cancer 2018, 125, 902-909. [CrossRef]

147. Kim, R.D.; Sanoff, H.K.; Poklepovic, A.S.; Soares, H.; Kim, J.; Lyu, J.; Liu, Y.; Nixon, A.B.; Kim, D.W. A multi-institutional phase 2 trial of regorafenib in refractory advanced biliary tract cancer. Cancer 2020, 126, 3464-3470. [CrossRef]

148. Demols, A.; Borbath, I.; Eynde, M.V.D.; Houbiers, G.; Peeters, M.; Marechal, R.; Delaunoit, T.; Goemine, J.-C.; Laurent, S.; Holbrechts, S.; et al. Regorafenib after failure of gemcitabine and platinum-based chemotherapy for locally advanced/metastatic biliary tumors: REACHIN, a randomized, double-blind, phase II trial. Ann. Oncol. 2020, 31, 1169-1177. [CrossRef] 
149. Golub, D.; Iyengar, N.; Dogra, S.; Wong, T.; Bready, D.; Tang, K.; Modrek, A.S.; Placantonakis, D.G. Mutant Isocitrate Dehydrogenase Inhibitors as Targeted Cancer Therapeutics. Front. Oncol. 2019, 9, 417. [CrossRef]

150. Abou-Alfa, G.K.; Macarulla, T.; Javle, M.M.; Kelley, R.K.; Lubner, S.J.; Adeva, J.; Cleary, J.M.; Catenacci, D.V.; Borad, M.J.; Bridgewater, J.; et al. Ivosidenib in IDH1-mutant, chemotherapy-refractory cholangiocarcinoma (ClarIDHy): A multicentre, randomised, double-blind, placebo-controlled, phase 3 study. Lancet Oncol. 2020, 21, 796-807. [CrossRef]

151. Borger, D.R.; Goyal, L.; Yau, T.C.C.; Poon, R.T.; Ancukiewicz, M.; Deshpande, V.; Christiani, D.C.; Liebman, H.M.; Yang, H.; Kim, H.; et al. Circulating Oncometabolite 2-Hydroxyglutarate Is a Potential Surrogate Biomarker in Patients with Isocitrate Dehydrogenase-Mutant Intrahepatic Cholangiocarcinoma. Clin. Cancer Res. 2014, 20, 1884-1890. [CrossRef]

152. Kim, R.D.; McDonough, S.; El-Khoueiry, A.B.; Bekaii-Saab, T.S.; Stein, S.M.; Sahai, V.; Keogh, G.P.; Kim, E.J.; Baron, A.D.; Siegel, A.B.; et al. Randomised phase II trial (SWOG S1310) of single agent MEK inhibitor trametinib Versus 5-fluorouracil or capecitabine in refractory advanced biliary cancer. Eur. J. Cancer 2020, 130, 219-227. [CrossRef] [PubMed]

153. Bekaii-Saab, T.; Phelps, M.A.; Li, X.; Saji, M.; Goff, L.; Kauh, J.S.W.; O’Neil, B.H.; Balsom, S.; Balint, C.; Liersemann, R.; et al. Multi-Institutional Phase II Study of Selumetinib in Patients with Metastatic Biliary Cancers. J. Clin. Oncol. 2011, 29, $2357-2363$. [CrossRef]

154. Subbiah, V.; Lassen, U.; Élez, E.; Italiano, A.; Curigliano, G.; Javle, M.; de Braud, F.; Prager, G.W.; Greil, R.; Stein, A.; et al. Dabrafenib plus trametinib in patients with BRAFV600E-mutated biliary tract cancer (ROAR): A phase 2, open-label, single-arm, multicentre basket trial. Lancet Oncol. 2020, 21, 1234-1243. [CrossRef]

155. Jinawath, A.; Akiyama, Y.; Sripa, B.; Yuasa, Y. Dual blockade of the Hedgehog and ERK $1 / 2$ pathways coordinately decreases proliferation and survival of cholangiocarcinoma cells. J. Cancer Res. Clin. Oncol. 2006, 133, 271-278. [CrossRef] [PubMed]

156. Le, D.T.; Durham, J.N.; Smith, K.N.; Wang, H.; Bartlett, B.R.; Aulakh, L.K.; Lu, S.; Kemberling, H.; Wilt, C.; Luber, B.S.; et al Mismatch repair deficiency predicts response of solid tumors to PD-1 blockade. Science 2017, 357, 409-413. [CrossRef] [PubMed]

157. Marabelle, A.; Le, D.T.; Ascierto, P.A.; Di Giacomo, A.M.; De Jesus-Acosta, A.; Delord, J.-P.; Geva, R.; Gottfried, M.; Penel, N.; Hansen, A.R.; et al. Efficacy of Pembrolizumab in Patients with Noncolorectal High Microsatellite Instability/Mismatch Repair-Deficient Cancer: Results from the Phase II KEYNOTE-158 Study. J. Clin. Oncol. 2020, 38, 1-10. [CrossRef] [PubMed]

158. Uenishi, T.; Yamazaki, O.; Tanaka, H.; Takemura, S.; Yamamoto, T.; Tanaka, S.; Nishiguchi, S.; Kubo, S. Serum Cytokeratin 19 Fragment (CYFRA21-1) as a Prognostic Factor in Intrahepatic Cholangiocarcinoma. Ann. Surg. Oncol. 2007, 15, 583-589. [CrossRef] [PubMed]

159. Liu, C.-H.; Huang, Q.; Jin, Z.-Y.; Xie, F.; Zhu, C.-L.; Liu, Z.; Wang, C. Circulating microRNA-21 as a prognostic, biological marker in cholangiocarcinoma. J. Cancer Res. Ther. 2018, 14, 220. [CrossRef]

160. Silakit, R.; Loilome, W.; Yongvanit, P.; Chusorn, P.; Techasen, A.; Boonmars, T.; Khuntikeo, N.; Chamadol, N.; Pairojkul, C.; Namwat, N. Circulating miR-192 in liver fluke-associated cholangiocarcinoma patients: A prospective prognostic indicator. $J$. Hepato-Biliary-Pancreat. Sci. 2014, 21, 864-872. [CrossRef]

161. Cheng, Q.; Feng, F.; Zhu, L.; Zheng, Y.; Luo, X.; Liu, C.; Yi, B.; Jiang, X. Circulating miR-106a is a Novel Prognostic and Lymph Node Metastasis Indicator for Cholangiocarcinoma. Sci. Rep. 2015, 5, 16103. [CrossRef]

162. Wang, L.-J.; Zhang, K.-L.; Zhang, N.; Ma, X.-W.; Yan, S.-W.; Cao, D.-H.; Shi, S.-J. Serum miR-26a as a diagnostic and prognostic biomarker in cholangiocarcinoma. Oncotarget 2015, 6, 18631-18640. [CrossRef] [PubMed]

163. Paolicchi, E.; Pacetti, P.; Giovannetti, E.; Mambrini, A.; Orlandi, M.; Crea, F.; Romani, A.A.; Tartarini, R.; Danesi, R.; Peters, G.J.; et al. A single nucleotide polymorphism in EZH2 predicts overall survival rate in patients with cholangiocarcinoma. Oncol. Lett. 2013, 6, 1487-1491. [CrossRef]

164. Khunluck, T.; Kukongviriyapan, V.; Puapairoj, A.; Khuntikeo, N.; Senggunprai, L.; Zeekpudsa, P.; Prawan, A. Association of NRF2 polymorphism with cholangiocarcinoma prognosis in Thai patients. Asian Pac. J. Cancer Prev. 2014, 15, 299-304. [CrossRef]

165. Meng, Z.-W.; Liu, M.-C.; Hong, H.-J.; Du, Q.; Chen, Y.-L. Expression and prognostic value of soluble CD97 and its ligand CD55 in intrahepatic cholangiocarcinoma. Tumor Biol. 2017, 39, 1010428317694319. [CrossRef]

166. Kaira, K.; Sunose, Y.; Oriuchi, N.; Kanai, Y.; Takeyoshi, I. CD98 is a promising prognostic biomarker in biliary tract cancer. Hepatobiliary Pancreat. Dis. Int. 2014, 13, 654-657. [CrossRef]

167. Nepal, C.; O’Rourke, C.J.; Oliveira, D.N.P.; Taranta, A.; Shema, S.; Gautam, P.; Calderaro, J.; Barbour, A.; Raggi, C.; Wennerberg, K.; et al. Genomic perturbations reveal distinct regulatory networks in intrahepatic cholangiocarcinoma. Hepatology 2018, 68, 949-963. [CrossRef]

168. Miyamoto, M.; Ojima, H.; Iwasaki, M.; Shimizu, H.; Kokubu, A.; Hiraoka, N.; Kosuge, T.; Yoshikawa, D.; Kono, T.; Furukawa, H.; et al. Prognostic significance of overexpression of c-Met oncoprotein in cholangiocarcinoma. Br. J. Cancer 2011, 105, 131-138. [CrossRef]

169. Shi, X.-D.; Yu, X.-H.; Wu, W.-R.; Xu, X.-L.; Wang, J.-Y.; Xu, L.-B.; Zhang, R.; Liu, C. Dickkopf-1 expression is associated with tumorigenity and lymphatic metastasis in human hilar cholangiocarcinoma. Oncotarget 2016, 7, 70378-70387. [CrossRef]

170. Shi, R.-Y.; Yang, X.-R.; Shen, Q.-J.; Yang, L.-X.; Xu, Y.; Qiu, S.-J.; Sun, Y.-F.; Zhang, X.; Wang, Z.; Zhu, K.; et al. High expression of Dickkopf-related protein 1 is related to lymphatic metastasis and indicates poor prognosis in intrahepatic cholangiocarcinoma patients after surgery. Cancer 2012, 119, 993-1003. [CrossRef]

171. Sarcognato, S.; Gringeri, E.; Fassan, M.; Di Giunta, M.; Maffeis, V.; Guzzardo, V.; Cillo, U.; Guido, M. Prognostic role of BAP-1 and PBRM-1 expression in intrahepatic cholangiocarcinoma. Virchows Arch. 2018, 474, 29-37. [CrossRef] 
172. Li, B.; Tang, H.; Zhang, A.; Dong, J. Prognostic Role of Mucin Antigen MUC4 for Cholangiocarcinoma: A Meta-Analysis. PLoS ONE 2016, 11, e0157878. [CrossRef]

173. Higashi, M.; Yamada, N.; Yokoyama, S.; Kitamoto, S.; Tabata, K.; Koriyama, C.; Batra, S.K.; Yonezawa, S. Pathobiological Implications of MUC16/CA125 Expression in Intrahepatic Cholangiocarcinoma-Mass Forming Type. Pathobiology 2012, 79, 101-106. [CrossRef] [PubMed]

174. Chusorn, P.; Namwat, N.; Loilome, W.; Techasen, A.; Pairojkul, C.; Khuntikeo, N.; Dechakhamphu, A.; Talabnin, C.; ChanOn, W.; Ong, C.K.; et al. Overexpression of microRNA-21 regulating PDCD4 during tumorigenesis of liver fluke-associated cholangiocarcinoma contributes to tumor growth and metastasis. Tumor Biol. 2013, 34, 1579-1588. [CrossRef] [PubMed]

175. Zhou, M.-H.; Zhou, H.-W.; Liu, M.; Sun, J.-Z. The role of miR-92b in cholangiocarcinoma patients. Int. J. Biol. Markers 2018, 33, 293-300. [CrossRef] [PubMed]

176. Qiao, P.; Li, G.; Bi, W.; Yang, L.; Yao, L.; Wu, D. microRNA-34a inhibits epithelial mesenchymal transition in human cholangiocarcinoma by targeting Smad4 through transforming growth factor-beta/Smad pathway. BMC Cancer 2015, 15, 1-13. [CrossRef] [PubMed]

177. Wang, J.; Xie, C.; Pan, S.; Liang, Y.; Han, J.; Lan, Y.; Sun, J.; Li, K.; Sun, B.; Yang, G. N-myc downstream-regulated gene 2 inhibits human cholangiocarcinoma progression and is regulated by leukemia inhibitory factor/MicroRNA-181c negative feedback pathway. Hepatology 2016, 64, 1606-1622. [CrossRef] [PubMed]

178. Li, H.; Zhou, Z.-Q.; Yang, Z.-R.; Tong, D.-N.; Guan, J.; Shi, B.-J.; Nie, J.; Ding, X.-T.; Li, B.; Zhou, G.-W.; et al. MicroRNA-191 acts as a tumor promoter by modulating the TET1-p53 pathway in intrahepatic cholangiocarcinoma. Hepatology 2017, 66, 136-151. [CrossRef]

179. Chen, Y.; Luo, J.; Tian, R.; Sun, H.; Zou, S. miR-373 Negatively Regulates Methyl-CpG-Binding Domain Protein 2 (MBD2) in Hilar Cholangiocarcinoma. Am. J. Dig. Dis. 2010, 56, 1693-1701. [CrossRef]

180. Li, J.; Yao, L.; Li, G.; Ma, D.; Sun, C.; Gao, S.; Zhang, P.; Gao, F. miR-221 Promotes Epithelial-Mesenchymal Transition through Targeting PTEN and Forms a Positive Feedback Loop with $\beta$-catenin/c-Jun Signaling Pathway in Extra-Hepatic Cholangiocarcinoma PLoS ONE 2015, 10, e0141168. [CrossRef]

181. Bridgewater, J.; Lopes, A.; Beare, S.; Duggan, M.; Lee, D.; Ricamara, M.; McEntee, D.; Sukumaran, A.; Wasan, H.; Valle, J.W. A phase $1 \mathrm{~b}$ study of Selumetinib in combination with Cisplatin and Gemcitabine in advanced or metastatic biliary tract cancer: The ABC-04 study. BMC Cancer 2016, 16, 153. [CrossRef]

182. Ikeda, M.; Ioka, T.; Fukutomi, A.; Morizane, C.; Kasuga, A.; Takahashi, H.; Todaka, A.; Okusaka, T.; Creasy, C.L.; Gorman, S.; et al. Efficacy and safety of trametinib in Japanese patients with advanced biliary tract cancers refractory to gemcitabine. Cancer Sci. 2017, 109, 215-224. [CrossRef]

183. Abou-Alfa, G.K.; Sahai, V.; Hollebecque, A.; Vaccaro, G.; Melisi, D.; Al-Rajabi, R.; Paulson, A.S.; Borad, M.J.; Gallinson, D.; Murphy, A.G.; et al. Pemigatinib for previously treated, locally advanced or metastatic cholangiocarcinoma: A multicentre, open-label, phase 2 study. Lancet Oncol. 2020, 21, 671-684. [CrossRef]

184. Goff, L.W.; Cardin, D.B.; Whisenant, J.G.; Du, L.; Koyama, T.; Dahlman, K.B.; Salaria, S.N.; Young, R.T.; Ciombor, K.K.; Gilbert, J.; et al. A phase I trial investigating pulsatile erlotinib in combination with gemcitabine and oxaliplatin in advanced biliary tract cancers. Investig. New Drugs 2016, 35, 95-104. [CrossRef]

185. Chiorean, E.G.; Ramasubbaiah, R.; Yu, M.; Picus, J.; Bufill, J.A.; Tong, Y.; Coleman, N.; Johnston, E.L.; Currie, C.; Loehrer, P.J Phase II Trial of Erlotinib and Docetaxel in Advanced and Refractory Hepatocellular and Biliary Cancers: Hoosier Oncology Group GI06-101. Oncologist 2012, 17, 13. [CrossRef]

186. Kim, S.T.; Jang, K.-T.; Lee, S.J.; Jang, H.-L.; Lee, J.; Park, S.H.; Park, Y.S.; Lim, H.Y.; Kang, W.K.; Park, J.O. Tumour shrinkage at 6 weeks predicts favorable clinical outcomes in a phase III study of gemcitabine and oxaliplatin with or without erlotinib for advanced biliary tract cancer. BMC Cancer 2015, 15, 530. [CrossRef]

187. Moehler, M.; Maderer, A.; Ehrlich, A.; Foerster, F.; Schad, A.; Nickolay, T.; Ruckes, C.; Weinmann, A.; Sivanathan, V.; Marquardt, J.U.; et al. Safety and efficacy of afatinib as add-on to standard therapy of gemcitabine/cisplatin in chemotherapynaive patients with advanced biliary tract cancer: An open-label, phase I trial with an extensive biomarker program. BMC Cancer 2019, 19, 55. [CrossRef]

188. Jeong, H.; Jeong, J.; Kim, K.-P.; Lee, S.; Oh, D.; Park, D.; Song, T.; Park, Y.; Hong, S.-M.; Ryoo, B.-Y.; et al. Feasibility of HER2Targeted Therapy in Advanced Biliary Tract Cancer: A Prospective Pilot Study of Trastuzumab Biosimilar in Combination with Gemcitabine Plus Cisplatin. Cancers 2021, 13, 161. [CrossRef]

189. Arkenau, H.-T.; Martin-Liberal, J.; Calvo, E.; Penel, N.; Krebs, M.G.; Herbst, R.S.; Walgren, R.A.; Widau, R.C.; Mi, G.; Jin, J.; et al. Ramucirumab Plus Pembrolizumab in Patients with Previously Treated Advanced or Metastatic Biliary Tract Cancer: Nonrandomized, Open-Label, Phase I Trial (JVDF). Oncologist 2018, 23, 1407-e136. [CrossRef]

190. Hu, Y.; Lin, H.; Hao, M.; Zhou, Y.; Chen, Q.; Chen, Z. Efficacy and Safety of Apatinib in Treatment of Unresectable Intrahepatic Cholangiocarcinoma: An Observational Study. Cancer Manag. Res. 2020, 12, 5345-5351. [CrossRef]

191. Zhang, G.; Gong, S.; Pang, L.; Hou, L.; He, W. Efficacy and Safety of Apatinib Treatment for Advanced Cholangiocarcinoma After Failed Gemcitabine-Based Chemotherapy: An Open-Label Phase II Prospective Study. Front. Oncol. 2021, 11, 3965. [CrossRef]

192. Wang, D.; Yang, X.; Long, J.; Lin, J.; Mao, J.; Xie, F.; Wang, Y.; Wang, Y.; Xun, Z.; Bai, Y.; et al. The Efficacy and Safety of Apatinib Plus Camrelizumab in Patients with Previously Treated Advanced Biliary Tract Cancer: A Prospective Clinical Study. Front. Oncol. 2021, 11, e646979. [CrossRef] [PubMed] 
193. Sgouros, J.; Aravantinos, G.; Koliou, G.-A.; Pentheroudakis, G.; Zagouri, F.; Psyrri, A.; Lampropoulou, D.I.; Demiri, S.; Pectasides, D.; Razis, E.; et al. First Line Gemcitabine/Pazopanib in Locally Advanced and/or Metastatic Biliary Tract Carcinoma. A Hellenic Cooperative Oncology Group Phase II Study. Anticancer Res. 2020, 40, 929-938. [CrossRef] [PubMed]

194. Santoro, A.; Gebbia, V.; Pressiani, T.; Testa, A.; Personeni, N.; Bajardi, E.A.; Foa, P.; Buonadonna, A.; Bencardino, K.; Barone, C.; et al. A randomized, multicenter, phase II study of vandetanib monotherapy versus vandetanib in combination with gemcitabine versus gemcitabine plus placebo in subjects with advanced biliary tract cancer: The VanGogh study. Ann. Oncol. 2014, 26, 542-547. [CrossRef] [PubMed]

195. Assenat, E.; Portales, F.; Ychou, M. A multicenter phase ib-IIR trial assessing activity of regorafenib in combination with modified gemcitabine-oxaliplatin (mGEMOX) in patients with advanced biliary tract cancer (aBTC). J. Clin. Oncol. 2018, 36, 427. [CrossRef]

196. Xu, J.; Bai, Y.; Sun, H.; Bai, C.; Jia, R.; Li, Y.; Zhang, W.; Liu, L.; Huang, C.; Guan, M.; et al. A single-arm, multicenter, open-label phase 2 trial of surufatinib in patients with unresectable or metastatic biliary tract cancer. Cancer 2021, 127, 3975-3984. [CrossRef]

197. Ueno, M.; Ikeda, M.; Sasaki, T.; Nagashima, F.; Mizuno, N.; Shimizu, S.; Ikezawa, H.; Hayata, N.; Nakajima, R.; Morizane, C. Phase 2 study of lenvatinib monotherapy as second-line treatment in unresectable biliary tract cancer: Primary analysis results. BMC Cancer 2020, 20, v246. [CrossRef] [PubMed]

198. Doi, T.; Yamamoto, N.; Naito, Y.; Kuboki, Y.; Koyama, T.; Piao, Y.; Tsujimoto, N.; Asou, H.; Inoue, K.; Kondo, S. Merestinib monotherapy or in combination for japanese patients with advanced and/or metastatic cancer: A phase 1 study. Cancer Med. 2021, 10, 6579-6589. [CrossRef] [PubMed]

199. Hack, S.P.; Verret, W.; Mulla, S.; Liu, B.; Wang, Y.; Macarulla, T.; Ren, Z.; El-Khoueiry, A.B.; Zhu, A.X. IMbrave 151: A randomized phase II trial of atezolizumab combined with bevacizumab and chemotherapy in patients with advanced biliary tract cancer. Ther. Adv. Med Oncol. 2021, 13, 17588359211036544. [CrossRef] 